Keywords: DWPF, SME, System Plan, PCCS, MAR

Retention: Permanent

\title{
MAR ASSESSMENTS OF THE HIGH LEVEL WASTE SYSTEM PLAN REVISION 16
}

D.K. Peeler

T.B. Edwards

August 2011

Savannah River National Laboratory Savannah River Nuclear Solutions, LLC Aiken, SC 29808

Prepared for the U.S. Department of Energy under contract number DE-AC09-08SR22470.

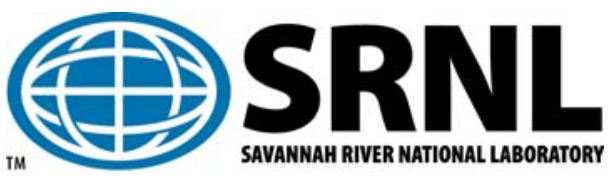


SRNL-STI-2011-00358

Revision 0

\section{DISCLAIMER}

This work was prepared under an agreement with and funded by the U.S. Government. Neither the U.S. Government or its employees, nor any of its contractors, subcontractors or their employees, makes any express or implied:

1. warranty or assumes any legal liability for the accuracy, completeness, or for the use or results of such use of any information, product, or process disclosed; or

2. representation that such use or results of such use would not infringe privately owned rights; or

3. endorsement or recommendation of any specifically identified commercial product, process, or service.

Any views and opinions of authors expressed in this work do not necessarily state or reflect those of the United States Government, or its contractors, or subcontractors.

\section{Printed in the United States of America}

Prepared for U.S. Department of Energy 


\section{REVIEWS AND APPROVALS}

\section{AUTHORS:}

D.K. Peeler, Process Technology Programs

Date

T.B. Edwards, Applied Computational Engineering and Statistics

Date

TECHNICAL REVIEW:

K.M. Fox, Process Technology Programs

Date

\section{APPROVALS:}

C. C. Herman, Manager

Date

Process Technology Programs

S.L. Marra, Manager

Date

Environmental \& Chemical Process Technology Research Programs

J. E. Occhipinti, Manager

Date

Waste Solidification Engineering 


\section{EXECUTIVE SUMMARY}

Savannah River Remediation (SRR) recently requested the Savannah River National Laboratory (SRNL) to perform a paper study assessment using future sludge projections to evaluate whether the current Process Composition Control System (PCCS) algorithms would provide projected operating windows to allow future contractual waste loading (WL) targets to be met. More specifically, the objective of this study was to evaluate future sludge batch projections (based on Revision 16 of the High Level Waste Systems Plan) with respect to projected operating windows using current PCCS models and associated constraints.

Based on the results of the Nominal Stage assessments of the SB9 through SB17 projections, projected operating windows of at least as low as 30\% with upper WLs exceeding $46 \% \mathrm{WL}$ are achievable with current PCCS models for all future sludge batches (sludge-only and Salt Waste Processing Facility (SWPF) based). Although these operating windows are encouraging from the perspective of meeting the future contractual WL obligations of $40 \%$, a significant concern in presenting the relatively large operating windows from a Nominal Stage perspective is the realization that the assessments do not account for potential sludge/waste variation. The results of the Variation Stage assessments show significant, negative reductions in the projected operating windows over which all of the extreme vertices can be processed. Application of the variation typically resulted in an 8 to $10 \%$ WL reduction in the operating window as compared to the Nominal Stage assessment window. This significant reduction occurred for "optimal" frits as well as "robust" frits suggesting that the ability to target a nominal WL of $40 \%$, while maintaining all of the extreme vertices as acceptable, will be extremely challenging for future Defense Waste Processing Facility (DWPF) operations based on the Revision 16 projections.

Based on the Measurement Acceptability Region (MAR) assessments performed in this study, it is clear that meeting future contractual WL targets in DWPF will be difficult. That is, if one continues to use the existing PCCS models, the current (or defined) WL metrics for acceptability (operating windows) and the standard system approaches or assumptions (e.g., magnitude of variation applied to the sludge compositions), the ability to meet future contractual WL obligations will be extremely challenging. These results obviously indicate or dictate the need for alternative approaches to be considered. Potential changes to the development strategy include: (a) integrating MAR assessments into the retrieval/blending strategy used in developing future sludge batches, (b) updating or replacing current models implemented into PCCS to account for higher waste loadings, or (c) assuming more processing risk through alternative metrics to define "acceptable" operating windows. The decision to implement alternative strategies, models, or approaches may ultimately be based on a balance between risk (operational) and reward (WL expectations.

Based on these initial assessments, SRNL recommends an integration of the MAR assessment approach with SRR HLW Systems Planning to evaluate whether alternative retrieval and blending strategies could provide access to higher WLs that will meet contractual obligations. SRNL sees this integration as a necessary step. Other alternative strategies including revisions to current models or changes to how acceptability is defined should also be developed in parallel. 


\section{TABLE OF CONTENTS}

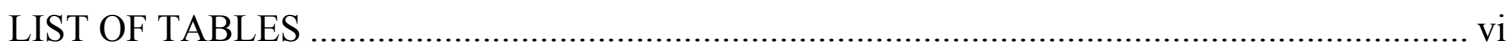

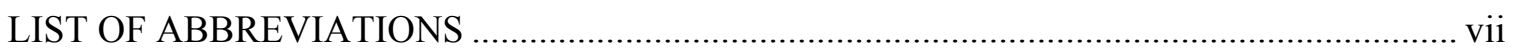

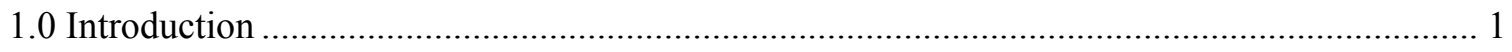

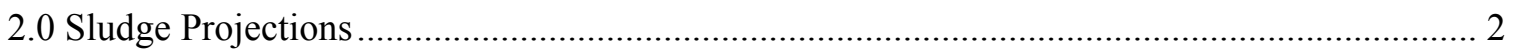

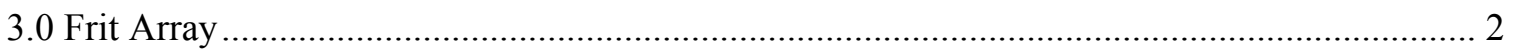

4.0 Measurement Acceptability Region (MAR) Assessments ...................................................... 3

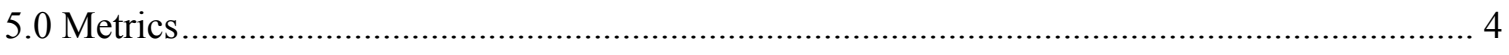

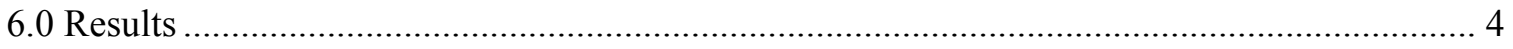

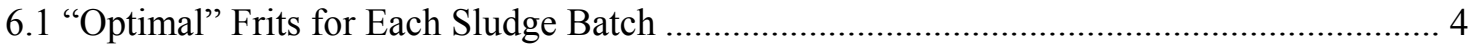

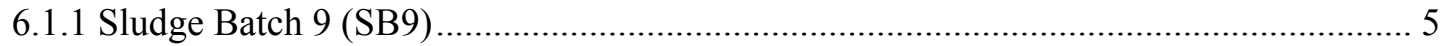

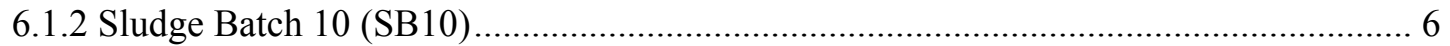

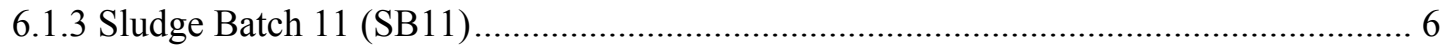

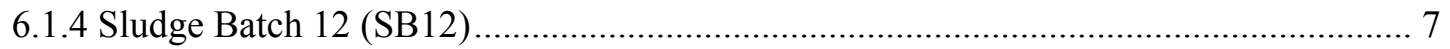

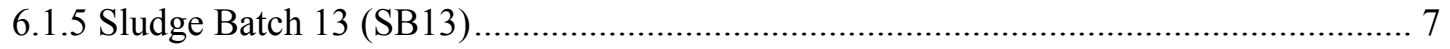

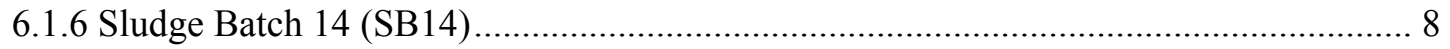

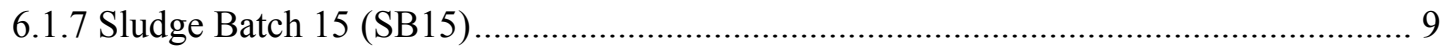

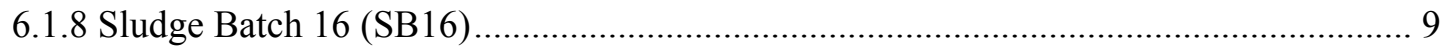

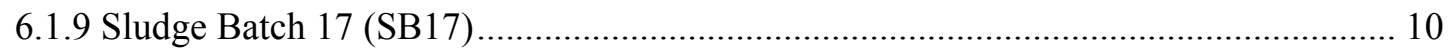

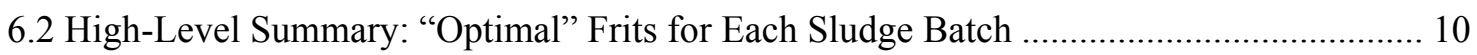

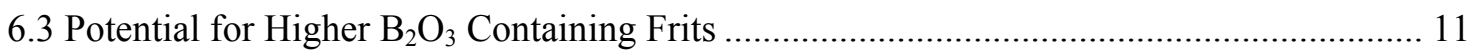

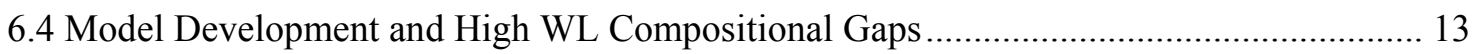

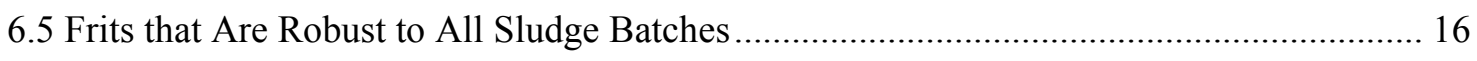

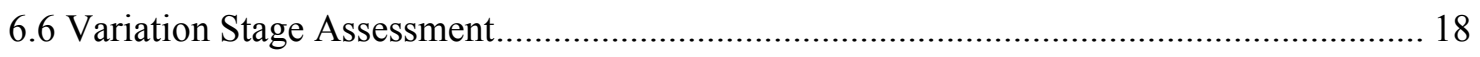

7.0 Discussion: Possible Solutions or Alternative Approaches................................................... 21

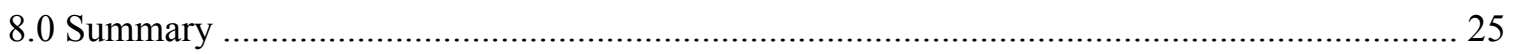

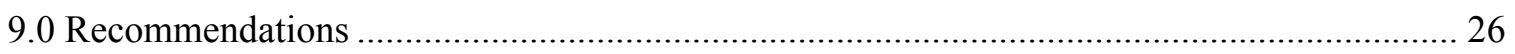

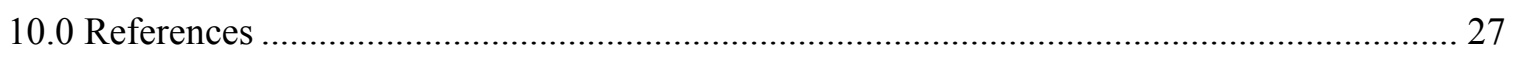

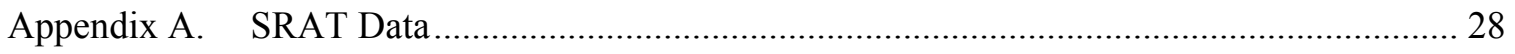




\section{LIST OF TABLES}

Table 1. Concentration Ranges for Components of the Four-Component Frit Composition Array.

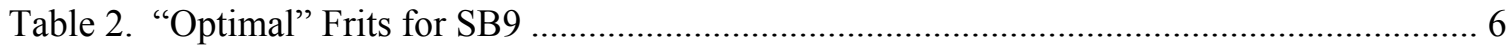

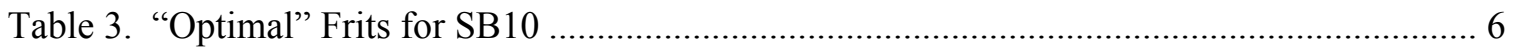

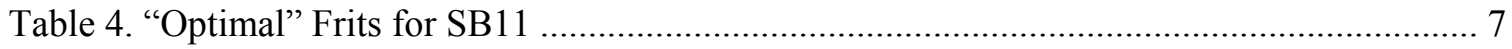

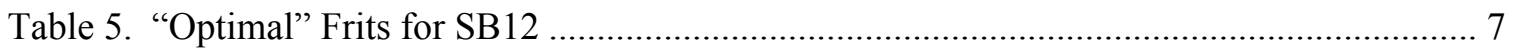

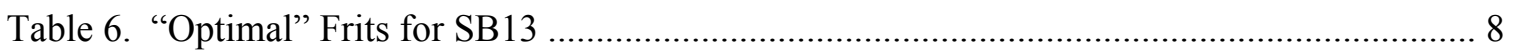

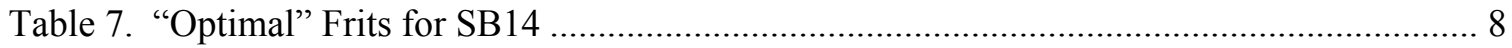

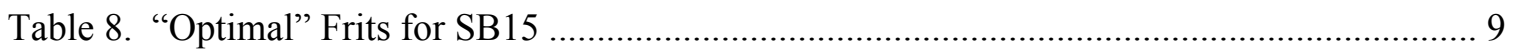

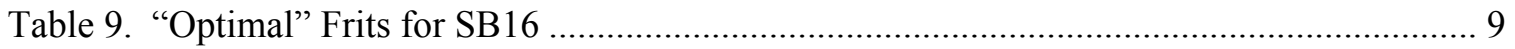

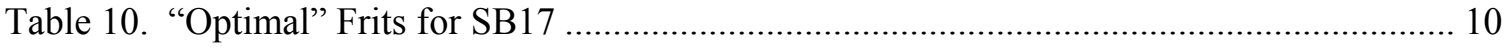

Table 11. Impact of Increasing $\mathrm{B}_{2} \mathrm{O}_{3}$ and $\mathrm{Li}_{2} \mathrm{O}$ Contents in Frit on the Projected Operating Windows.

Table 12. Comparison of Projected Oxide Contents in Glass at Various WLs to the $\mathrm{T}_{\mathrm{L}}$ Model

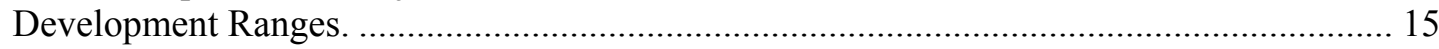

Table 13. Candidate Frits that are Robust to all Eighteen Projections (Sludge-only Options).... 17

Table 14. Candidate Frits that are Robust to all Eighteen Projections (SWPF-Based Options). . 18

Table 15. Results of Variation Stage Assessment for Each Sludge Batch using the $10 \% \mathrm{~B}_{2} \mathrm{O}_{3}$,

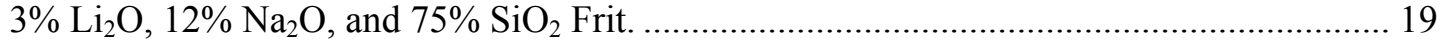

Table 16. Nominal and Variation Stage Assessments for SB9 with "Optimal” Frits. ................. 20

Table 17. Summary Statistics for the Fe and Na Measurements from Recent SRAT Receipt

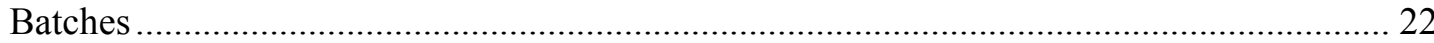




\section{LIST OF ABBREVIATIONS}

$\begin{array}{ll}\text { ARP } & \text { Actinide Removal Process } \\ \text { CPC } & \text { Chemical Process Cell } \\ \text { DOE } & \text { Department of Energy } \\ \text { DWPF } & \text { Defense Waste Processing Facility } \\ \text { EV } & \text { Extreme Vertice } \\ \text { HLW } & \text { High Level Waste } \\ \text { LE } & \text { Life Extension } \\ \text { MAR } & \text { Measurement Acceptability Region } \\ \text { MCU } & \text { Modular Caustic Side Solvent Extraction Unit } \\ \text { PCCS } & \text { Product Composition Control System } \\ \text { RSD } & \text { Relative Standard Deviation } \\ \text { SB } & \text { Sludge Batch } \\ \text { SCIX } & \text { Small Column Ion Exchange } \\ \text { SME } & \text { Slurry Mix Evaporator } \\ \text { SRAT } & \text { Sludge Receipt and Adjustment Tank } \\ \text { SRNL } & \text { Savannah River National Laboratory } \\ \text { SRR } & \text { Savannah River Remediation } \\ \text { SWPF } & \text { Salt Waste Processing Facility } \\ T_{L} & \text { Liquid Temperature } \\ \text { WL } & \text { Waste Loading }\end{array}$


SRNL-STI-2011-00358

Revision 0

\subsection{Introduction}

High-level waste (HLW) throughput (i.e., the amount of waste processed per unit of time) is primarily a function of two critical parameters: waste loading (WL) and melt rate. For the Defense Waste Processing Facility (DWPF), increasing HLW throughput would significantly reduce the overall mission life cycle costs for the Department of Energy (DOE). Significant increases in waste throughput have been achieved at DWPF since initial radioactive operations began in 1996. Key technical and operational initiatives that supported increased waste throughput included improvements in facility attainment, the Chemical Processing Cell (CPC) flowsheet, process control models and frit formulations. ${ }^{1}$ As a result of these key initiatives, DWPF increased WLs from a nominal 28\% for Sludge Batch 2 (SB2) to 34 to 38\% for SB3 through SB6 while maintaining or slightly improving canister fill times. Although considerable improvements in waste throughput have been obtained, future contractual waste loading targets are nominally $40 \%$, while canister production rates are also expected to increase (to a rate of 325 to 400 canisters per year). Although implementation of bubblers have made a positive impact on increasing melt rate for recent sludge batches targeting WLs in the mid30s, higher WLs will ultimately make the feeds to DWPF more challenging to process.

Savannah River Remediation (SRR) recently requested the Savannah River National Laboratory (SRNL) to perform a paper study assessment using future sludge projections to evaluate whether the current Process Composition Control System (PCCS) algorithms would provide projected operating windows to allow future contractual WL targets to be met. ${ }^{*}$ More specifically, the objective of this study was to evaluate future sludge batch projections (based on Revision 16 of the HLW Systems Plan) ${ }^{2}$ with respect to projected operating windows using current PCCS models and associated constraints. Based on the assessments, the waste loading interval over which a glass system (i.e., a projected sludge composition with a candidate frit) is predicted to be acceptable can be defined (i.e., the projected operating window) which will provide insight into the ability to meet future contractual WL obligations. In this study, future contractual WL obligations are assumed to be $40 \%$, which is the goal after all flowsheet enhancements have been implemented to support DWPF operations. For a system to be considered acceptable, candidate frits must be identified that provide access to at least $40 \% \mathrm{WL}$ while accounting for potential variation in the sludge resulting from differences in batch-to-batch transfers into the Sludge Receipt and Adjustment Tank (SRAT) and/or analytical uncertainties.

In more general terms, this study will assess whether or not the current glass formulation strategy (based on the use of the Nominal and Variation Stage assessments) ${ }^{3}$ and current PCCS models will allow access to compositional regions required to targeted higher WLs for future operations. Some of the key questions to be considered in this study include:

(1) If higher WLs are attainable with current process control models, are the models valid in these compositional regions? ${ }^{\dagger}$ If the higher WL glass regions are outside current model development or validation ranges, is there existing data that could be used to demonstrate model applicability (or lack thereof)? If not, experimental data may be required to revise current models or serve as validation data with the existing models. ${ }^{*}$

(2) Are there compositional trends in frit space that are required by the PCCS models to obtain access to these higher WLs? If so, are there potential issues with the compositions of the associated frits (e.g., limitations on the $\mathrm{B}_{2} \mathrm{O}_{3}$ and/or $\mathrm{Li}_{2} \mathrm{O}$ concentrations) as they are compared to model

\footnotetext{
${ }^{*}$ Technical Assistance Request, HLW-DWPF-TAR-2011-0003, Initiator: E.W. Holtzscheiter, May 30, 2011.

$\dagger$ The review of model development ranges in this study is restricted to those associated with the $\mathrm{T}_{\mathrm{L}}$ model given they are readily available.

† If so, an experimental plan will be developed for SRR's review and approval.
} 
development/validation ranges or to the term "borosilicate" glass? If limitations on the frit compositional range are realized, what is the impact of these restrictions on other glass properties such as the ability to suppress nepheline formation or influence melt rate?

The model based assessments being performed make the assumption that the process control models are applicable over the glass compositional regions being evaluated. Although the glass compositional region of interest is ultimately defined by the specific frit, sludge, and WL interval used, there is no prescreening of these compositional regions with respect to the model development or validation ranges which is consistent with current DWPF operations.

\subsection{Sludge Projections}

SRR provided sludge only and Salt Waste Processing Facility (SWPF)-based projections for SB9 through SB17 based on Revision 16 of the HLW System Plan. ${ }^{*}$ The projections did not include noble metals or account for other secondary waste streams such as those from the Actinide Removal Process / Modular Caustic Side Solvent Extraction Unit (ARP/MCU), Small Column Ion Exchange (SCIX), and the new Life Extension (LE) solvent (boric acid), or other potential streams that may be introduced into the SRAT and ultimately must be accounted for through glass formulation efforts. As an example, introduction of the SCIX and SWPF streams into the DWPF flowsheet is anticipated to yield $\mathrm{TiO}_{2}$ concentrations in glass up to approximately $6 \mathrm{wt} \%{ }^{4}$ The compositional projections received from SRR have maximum $\mathrm{TiO}_{2}$ contents of approximately $4.1 \mathrm{wt} \%$ on a calcined sludge basis and even assuming a $\mathrm{WL}$ of $50 \%, \mathrm{TiO}_{2}$ concentrations in glass would only be on the order of $\sim 2 \mathrm{wt} \%$. Thus, while the Measurement Acceptability Region (MAR) assessments were performed with the current sludge projections, it is recommended that SRNL and SRR reevaluate future sludge batch projections to ensure that the projections appropriately include any planned future operations (i.e., the various salt operations and/or LE projects either come on line or are replaced by more efficient operations).

Capturing future projections as accurately as possible is critical given candidate frits must be robust to the streams that ultimately compose a specific sludge batch which could include particular streams being metered in only during a portion of the sludge batch processing. For example, previous frit development efforts have ensured that the frits recommended for DWPF processing are tolerant to sludge-only and coupled operations (based on ARP/MCU) given non-continuous introduction of ARP/MCU into the SRAT. Assuming that SRR will continue to need the flexibility of adding auxiliary streams during DWPF processing, more refined projections from SRR will be needed that take into account when all secondary streams from other unit operations are introduced or removed from the overall DWPF flowsheet.

\subsection{Frit Array}

A frit compositional array was developed based on the four primary oxides $\left(\mathrm{B}_{2} \mathrm{O}_{3}, \mathrm{Li}_{2} \mathrm{O}, \mathrm{Na}_{2} \mathrm{O}\right.$, and $\left.\mathrm{SiO}_{2}\right)$ currently being used to support DWPF processing. Concentration ranges for each of the four components are listed in Table 1. The concentrations of $\mathrm{B}_{2} \mathrm{O}_{3}, \mathrm{Li}_{2} \mathrm{O}$, and $\mathrm{Na}_{2} \mathrm{O}$ were varied in 1 wt $\%$ increments leading to a total of 2,873 different frit compositions based on the various combinations. Note that the $\mathrm{SiO}_{2}$ concentration for each potential frit was determined directly from the other three concentrations (i.e., it was used to balance the frit composition to $100 \mathrm{wt} \%$ ).

\footnotetext{
${ }^{*}$ It is noted that a sludge-only projection of SB8 was also provided in Rev 16. SRNL elected not to include this sludge batch in the current assessment as it will be the focus of a specific or direct effort in the near future.
} 
SRNL-STI-2011-00358

Revision 0

Table 1. Concentration Ranges for Components of the Four-Component Frit Composition Array.

\begin{tabular}{|c|c|}
\hline Frit Oxide & $\begin{array}{c}\text { Concentration Range } \\
\text { (wt \%) }\end{array}$ \\
\hline $\mathrm{B}_{2} \mathrm{O}_{3}$ & $8-20$ \\
\hline $\mathrm{Li}_{2} \mathrm{O}$ & $2-14$ \\
\hline $\mathrm{Na}_{2} \mathrm{O}$ & $0-16$ \\
\hline $\mathrm{SiO}_{2}$ & $50-90$ \\
\hline
\end{tabular}

\subsection{Measurement Acceptability Region (MAR) Assessments}

Each of the 2,873 frits was coupled with each nominal sludge projection (SB9 through SB17 both sludgeonly and SWPF-based) over a WL interval of $25-50 \%$. Predicted glass properties for each frit-sludge system over the $25-50 \%$ WL interval were compared to current Slurry Mix Evaporator (SME) acceptability constraints (using the MAR criteria). ${ }^{5}$ Projected operating windows were defined by the WL interval over which glasses (within a specific frit-sludge system) were deemed acceptable by the current models and their associated constraints. It should be noted that a $\mathrm{SO}_{4}$ limit, the current $2.0 \mathrm{wt} \%$ $\mathrm{TiO}_{2}$ limit, and homogeneity restrictions with $\mathrm{TiO}_{2}$ contents above $2 \mathrm{wt} \%$ were not imposed as restrictions on upper or lower WLs. As previously mentioned, it is assumed that the current models are applicable over the compositional regions to which they are being applied. That is, there are associated model development and validation ranges for each of the process control models. When higher WLs are targeted, there could be a single oxide or combination of oxides that are outside the concentrations used to develop and/or validate specific models. Therefore, the assumption being made is that the models are applicable in the compositional regions (based on the frit compositions, sludge compositions, and WL interval) being addressed in this assessment (see Section 7.0 for more discussion on this issue).

With respect to the $\mathrm{SO}_{4}$ concentrations, based on the SRR sludge-only and SWPF-based projections, the $\mathrm{SO}_{4}$ contents in calcine sludge range from approximately 1 to $1.3 \mathrm{wt} \%$. At 40 and $50 \% \mathrm{WL}$, this would translate into targeted $\mathrm{SO}_{4}$ contents in glass of 0.4 to $0.65 \mathrm{wt} \%$, respectively. It is recognized that each sludge batch projection is based on an assumed washing strategy which could change prior to processing the specific sludge batch. However, future washing or blending strategy changes can not be anticipated. Given the current $\mathrm{PCCS} \mathrm{SO}_{4}$ limit of $0.6 \mathrm{wt} \%$ (in glass) and the projected $\mathrm{SO}_{4}$ concentrations in sludge, there is no real concern that the projected operating windows presented in this study will be overly exaggerated with respect to $\mathrm{SO}_{4}$ retention or solubility.

With respect to $\mathrm{TiO}_{2}$, the compositional projections received from SRR had maximum $\mathrm{TiO}_{2}$ contents of approximately $4.1 \mathrm{wt} \%$ on a calcined sludge basis for SB11, SB12, and SB13. As previously mentioned, even assuming future WL targets of $50 \%, \mathrm{TiO}_{2}$ concentrations in glass would only be on the order of 2 wt \% which is the current $\mathrm{TiO}_{2}$ upper limit for solubility in PCCS and the upper limit for the current $\mathrm{T}_{\mathrm{L}}$ model with respect to applicability. Therefore, ignoring the $\mathrm{TiO}_{2}$ constraint does not have any significant impact on the outcome of this study. 
SRNL-STI-2011-00358

Revision 0

\subsection{Metrics}

To support programmatic objectives, metrics with respect to the definition of an acceptable processing window were needed to classify the MAR results and ultimately to provide insightful conclusions to SRR. Given the focus of this study was to assess whether future contractual WLs (assumed to be 40\%) can be attained, a minimum upper WL of at least as high as $45 \%$ WL was used during the Nominal Stage assessments. That is, the specific frit-sludge system of interest had to provide access to at least $45 \% \mathrm{WL}$ (or higher) for both the sludge-only and SWPF-based nominal projections. The use of a $45 \%$ upper WL minimum was thought to be high enough to provide access to at least $40 \% \mathrm{WL}$ once sludge variation was accounted for during the Variation Stage assessments. Given the definition of a minimum upper WL (45\%), the lower WL was set to at least as low as $30 \%$. Therefore, to be considerable acceptable, projected operating windows must provide access to at least as low as $30 \% \mathrm{WL}$ up to at least as high as $45 \% \mathrm{WL}$. It is recognized that defining an acceptable operating window using these criteria is subjective but nonetheless required to provide guidelines from which programmatic objectives can be measured.

Using the definition of an acceptable processing window, there were two approaches taken to identify candidate frits and potential concerns for meeting future contractual WL obligations for the projected nominal sludge batches. The first approach identified "optimal" frits for each specific sludge batch. "Optimal" being defined as meeting the at least as low as 30\% WL up to the maximum allowable by the current process control models (assuming applicability) for both the sludge-only and SWPF-based nominal projections. That is, frits that provided the maximum upper WL (while meeting the lower limit of at least as low as $30 \%$ ) were identified regardless of their composition. ${ }^{*}$

The second approach was to identify viable frits that provide acceptable projected operating windows for not only one sludge batch but for all 18 nominal sludge projections (SB9 through SB17, sludge-only and SWPF). This approach may not be optimal for a specific sludge batch, but it does provide insight into candidate frits that are able to tolerate a larger compositional range of sludge oxides. This may be of interest relative to the continuity of the use of a frit over several sludge batches. In addition, identification of "robust" frits could be of significant value when assessing the impact of sludge variation on the projected operating windows (Variation Stage).

\subsection{Results}

\section{1 "Optimal” Frits for Each Sludge Batch}

The results of the MAR assessment to identify "optimal" frits for each sludge-batch are summarized in Section 6.1.1 (SB9) through Section 6.1.9 (SB17). For each sludge batch, frits that provide access to the maximum upper WL while still meeting the lower WL constraint for acceptability (i.e., at least as low as $30 \%$ ) are listed. The nomenclature used to identify the composition of the "optimal" frits is based on the wt $\%$ of $\mathrm{B}_{2} \mathrm{O}_{3}, \mathrm{Li}_{2} \mathrm{O}, \mathrm{Na}_{2} \mathrm{O}$, and $\mathrm{SiO}_{2}$, respectively. For example, a frit referred to as " $8,3,11,78$ " has 8 wt $\% \mathrm{~B}_{2} \mathrm{O}_{3}, 3$ wt $\% \mathrm{Li}_{2} \mathrm{O}, 11$ wt $\% \mathrm{Na}_{2} \mathrm{O}$, and 78 wt $\% \mathrm{SiO}_{2}$.

For some sludge batches, not all of the "optimal" frits are shown. In these situations, the frits were screened to show the maximum upper WL that could be achieved over some range of $\mathrm{B}_{2} \mathrm{O}_{3}$ or $\mathrm{Li}_{2} \mathrm{O}$

\footnotetext{
* Although frits may be identified that meet the established metrics for acceptability for both sludge-only and SWPF projections, as previously noted there may be other streams (such as ARP/MCU and SCIX) that were not included in this assessment. Therefore, identifying or recommending a frit for future DWPF processing based solely on this assessment is not advisable.
} 
SRNL-STI-2011-00358

Revision 0

concentrations. The processing constraints that limit access to lower and upper WLs are also shown for each frit-sludge system.

\subsubsection{Sludge Batch 9 (SB9)}

There were only two frits $(8,3,11,78$ and $9,2,12,77)$ that provided the maximum operating window of $30 \%$ up to $48 \%$ WL for both sludge-only (SO) and SWPF operations. Table 2 shows the composition of these two frits, the projected operating windows, and the limiting constraints. All of the systems shown in Table 2 are limited by predictions of high viscosity (high $\eta$ ) at WLs less than 30\% while predictions of low viscosity (low $\eta$ ) limit access to WLs of $49 \%$ and higher. These operating windows are very encouraging from the perspective of meeting future contractual WL obligations of $40 \%$. The question remaining is will application of sludge variation still provide access to WLs of at least $40 \%$ WL? This is a question that is answered by the Variation Stage assessments of Section 6.6.

The results of the SB9 Nominal Stage MAR assessment also suggest that maximum WL opportunities appear to be driven by lower $\mathrm{B}_{2} \mathrm{O}_{3}$ and $\mathrm{Li}_{2} \mathrm{O}$ concentrations in frit. For example, although the $\mathrm{B}_{2} \mathrm{O}_{3}$ content in the frit grid ranged from 8 to $20 \mathrm{wt} \%$ (see Table 1), the two "optimal" frits have $\mathrm{B}_{2} \mathrm{O}_{3}$ contents of 8 and $9 \mathrm{wt} \%$. Although not necessarily a technical concern, as higher WLs are targeted, the realization of a decreasing $\mathrm{B}_{2} \mathrm{O}_{3}$ content in glass must be accounted for to ensure that the production of a borosilicate glass is still maintained or that the $\mathrm{B}_{2} \mathrm{O}_{3}$ concentration remains within model development or validation ranges.

With respect to the low $\mathrm{Li}_{2} \mathrm{O}$ content, again this is not necessarily a technical issue but one associated with model development ranges. Given the $\mathrm{T}_{\mathrm{L}}$ model development ranges for $\mathrm{Li}_{2} \mathrm{O}$ in glass are readily available (2.49 to $6.16 \mathrm{wt} \%$ from Brown et al. ${ }^{6}$, these lower $\mathrm{Li}_{2} \mathrm{O}$ based frits ( 2 and $3 \mathrm{wt} \%$ in frit) cause some concern over model applicability in $\mathrm{T}_{\mathrm{L}}$-space. Therefore, although there are two frits identified in Table 2 that provide access to WLs up to $48 \%$, one may question the applicability of the $T_{L}$ model to the glass systems defined by their use (even though the upper WLs are low $\eta$ limited). If low $\mathrm{Li}_{2} \mathrm{O}$-based frits are identified as "optimal" for other future sludge batches, a detailed discussion of this issue will not be replicated - only mentioned. It should also be noted that any discussion of the relatively low $\mathrm{B}_{2} \mathrm{O}_{3}$ and/or $\mathrm{Li}_{2} \mathrm{O}$ contents with respect to $\mathrm{T}_{\mathrm{L}}$ model applicability is strictly related to the frit composition. ${ }^{*}$ That is, even if frits with $\mathrm{B}_{2} \mathrm{O}_{3}$ and $\mathrm{Li}_{2} \mathrm{O}$ contents are found that mitigate concerns over $\mathrm{T}_{\mathrm{L}}$ model applicability for these two oxides, there still may be applicability issues based on oxide concentrations contributed by sludge components. This latter issue is addressed in Section 6.4. Any discussion of $\mathrm{T}_{\mathrm{L}}$ model applicability issues in this section is strictly related to the frit contribution.

\footnotetext{
${ }^{*}$ As previously noted, the potential impacts addition $\mathrm{B}_{2} \mathrm{O}_{3}$ via the new LE Solvent (boric acid based) has not been accounted for in this study.
} 
SRNL-STI-2011-00358

Revision 0

Table 2. “Optimal” Frits for SB9

\begin{tabular}{||c|c|c|c|c||}
\hline \hline Sludge & \multirow{2}{*}{$\begin{array}{c}\text { Frit } \\
\text { (B,Li,Na,Si) }\end{array}$} & $\begin{array}{c}\text { Lower } \\
\text { Constraint }\end{array}$ & $\begin{array}{c}\text { Projected Window } \\
\text { (WL) }\end{array}$ & $\begin{array}{c}\text { Upper } \\
\text { Constraint(s) }\end{array}$ \\
\cline { 1 - 3 } SO & \multirow{2}{*}{$8,3,11,78$} & High $\eta$ & $30-48$ & Low $\eta$ \\
\cline { 1 - 4 } SWPF & & High $\eta$ & $30-48$ & Low $\eta$ \\
\hline SO & \multirow{2}{*}{$9,2,12,77$} & High $\eta$ & $30-48$ & Low $\eta$ \\
\cline { 1 - 4 } SWPF & & High $\eta$ & $30-48$ & Low $\eta$ \\
\hline
\end{tabular}

\subsubsection{Sludge Batch 10 (SB10)}

Six frits were identified as optimal for SB10; these provide operating windows of at least as low as $30 \%$ up to at least as high as $47 \%$ for both sludge-only and SWPF-based nominal projections. The projected operating windows are all high viscosity limited at lower WLs while predictions of $T_{L}$ or low viscosity limit access to higher WLs. Three of these six frits are shown in Table 3; these span the minimum and maximum $\mathrm{B}_{2} \mathrm{O}_{3}$ values for the six optimal frits. The maximum $\mathrm{Li}_{2} \mathrm{O}$ content of the six frits is $4 \mathrm{wt} \%$ (not shown in Table 3); so the issues of model applicability (at least for the $\mathrm{T}_{\mathrm{L}}$ model) are of concern for some of the SB10 systems being evaluated at higher WLs. Although some of the optimal frits contain 8 wt \% $\mathrm{B}_{2} \mathrm{O}_{3}$, there are options for higher $\mathrm{B}_{2} \mathrm{O}_{3}$ containing frits $(9$ or $10 \mathrm{wt} \%)$ to address the potential issues of low $\mathrm{B}_{2} \mathrm{O}_{3}$-containing glasses produced by DWPF. That being said, the maximum $\mathrm{B}_{2} \mathrm{O}_{3}$ content for the optimal frits is $10 \mathrm{wt} \%$, and although this lessens the issue of a lower $\mathrm{B}_{2} \mathrm{O}_{3}$ concentration in glass, it reiterates the fact that the optimal frits are still on the lower end of the $\mathrm{B}_{2} \mathrm{O}_{3}$ frit array. Therefore, if higher $\mathrm{B}_{2} \mathrm{O}_{3}$ frits are desired, the likelihood of finding a high $\mathrm{B}_{2} \mathrm{O}_{3}$-based frit that provides access to the maximum upper WL continues to be low.

Table 3. “Optimal” Frits for SB10

\begin{tabular}{|c|c|c|c|c|}
\hline Sludge & $\begin{array}{c}\text { Frit } \\
\text { (B,Li,Na,Si) }\end{array}$ & $\begin{array}{c}\text { Lower } \\
\text { Constraint }\end{array}$ & $\begin{array}{c}\text { Projected Window } \\
\text { (WL) }\end{array}$ & $\begin{array}{c}\text { Upper } \\
\text { Constraint(s) }\end{array}$ \\
\hline SO & \multirow[t]{2}{*}{$8,3,11,78$} & High $\eta$ & $30-47$ & $\mathrm{~T}_{\mathrm{L}}$ \\
\hline SWPF & & High $\eta$ & $30-48$ & Low $\eta$ \\
\hline SO & \multirow[t]{2}{*}{$9,2,12,77$} & High $\eta$ & $30-48$ & $\mathrm{~T}_{\mathrm{L}}$ \\
\hline SWPF & & $\operatorname{High} \eta$ & $30-48$ & Low $\eta$ \\
\hline SO & \multirow[t]{2}{*}{$10,2,12,76$} & High $\eta$ & $29-47$ & Low $\eta$ \\
\hline SWPF & & $\operatorname{High} \eta$ & $29-47$ & $\mathrm{~T}_{\mathrm{L}}$, Low $\eta$ \\
\hline
\end{tabular}

\subsubsection{Sludge Batch 11 (SB11)}

For SB11, seven frits were identified as optimal; these provide operating windows of at least as low as $28 \% \mathrm{WL}$ up to 46 to $48 \% \mathrm{WL}$ for both sludge-only and SWPF-based nominal projections. Table 4 summarizes three of the seven frits; these span the range of $\mathrm{B}_{2} \mathrm{O}_{3}$ contents of the optimal frits. Predictions of $T_{L}$, low $\eta$, or nepheline formation are limiting constraints for higher WLs in these systems, while predictions of high $\eta$ limit access to lower WLs for some systems. As with SB9 and SB10, the lower $\mathrm{Li}_{2} \mathrm{O}$ contents in frit are of concern with respect to $\mathrm{T}_{\mathrm{L}}$ model applicability at higher WLs. It is noted that the maximum $\mathrm{Li}_{2} \mathrm{O}$ content of the seven optimal frits was $4 \mathrm{wt} \%$ (not shown in Table 4). 
SRNL-STI-2011-00358

Revision 0

Table 4. “Optimal” Frits for SB11

\begin{tabular}{|c|c|c|c|c|}
\hline Sludge & $\begin{array}{c}\text { Frit } \\
(\mathrm{B}, \mathrm{Li}, \mathrm{Na}, \mathrm{Si})\end{array}$ & $\begin{array}{c}\text { Lower } \\
\text { Constraint }\end{array}$ & $\begin{array}{c}\text { Projected Window } \\
\text { (WL) }\end{array}$ & $\begin{array}{c}\text { Upper } \\
\text { Constraint(s) } \\
\end{array}$ \\
\hline SO & \multirow[t]{2}{*}{$8,2,14,76$} & High $\eta$ & $28-46$ & $\mathrm{~T}_{\mathrm{L}}$ \\
\hline SWPF & & High $\eta$ & $28-48$ & Low $\eta$, Neph \\
\hline SO & \multirow[t]{2}{*}{$8,3,13,76$} & - & $25-46$ & $\mathrm{~T}_{\mathrm{L}}$ \\
\hline SWPF & & High $\eta$ & $26-48$ & Low $\eta$ \\
\hline SO & \multirow[t]{2}{*}{$10,2,14,76$} & - & $25-46$ & $T_{L}$, Low $\eta$, Neph \\
\hline SWPF & & - & $25-46$ & Low $\eta$ \\
\hline
\end{tabular}

\subsubsection{Sludge Batch 12 (SB12)}

Based on the Nominal Stage MAR results, four frits were identified as optimal for SB12; these provide operating windows of $25 \% \mathrm{WL}$ up to at least 47 or $48 \% \mathrm{WL}$. Table 5 summarizes the MAR results for these four frits. Given $25 \% \mathrm{WL}$ is acceptable for all four systems, there is no lower WL constraints. At the upper WLs, predictions of $\mathrm{T}_{\mathrm{L}}$, nepheline formation, and/or low $\eta$ limit access to higher WLs. With respect to the $\mathrm{Li}_{2} \mathrm{O}$ concentrations, all four frits have higher $\mathrm{Li}_{2} \mathrm{O}$ contents $(>5 \mathrm{wt} \%$ ), which minimizes the concerns over $\mathrm{T}_{\mathrm{L}}$ model applicability at higher WLs. The $\mathrm{B}_{2} \mathrm{O}_{3}$ contents range from 8 to 9 wt $\%$ which is consistent with previous systems suggesting that the maximum upper WLs are based on lower $\mathrm{B}_{2} \mathrm{O}_{3}$ containing frits.

Table 5. “Optimal” Frits for SB12

\begin{tabular}{|c|c|c|c|c|}
\hline Sludge & $\begin{array}{c}\text { Frit } \\
(\mathrm{B}, \mathrm{Li}, \mathrm{Na}, \mathrm{Si})\end{array}$ & $\begin{array}{c}\text { Lower } \\
\text { Constraint }\end{array}$ & $\begin{array}{c}\text { Projected } \\
\text { Window (WL) }\end{array}$ & $\begin{array}{c}\text { Upper } \\
\text { Constraint(s) }\end{array}$ \\
\hline SO & \multirow[t]{2}{*}{$8,6,10,76$} & - & $25-47$ & $\mathrm{~T}_{\mathrm{L}}, \mathrm{Neph}$ \\
\hline SWPF & & - & $25-48$ & Low $\eta$, Neph \\
\hline SO & \multirow[t]{2}{*}{$9,6,10,75$} & - & $25-47$ & $\mathrm{~T}_{\mathrm{L}}$, Low $\eta$, Neph \\
\hline SWPF & & - & $25-47$ & Low $\eta$, Neph \\
\hline SO & \multirow[t]{2}{*}{$8,5,11,76$} & - & $25-47$ & $\mathrm{~T}_{\mathrm{L}}, \mathrm{Neph}$ \\
\hline SWPF & & - & $25-47$ & Neph \\
\hline SO & \multirow[t]{2}{*}{$8,7,9,76$} & - & $25-47$ & $\mathrm{~T}_{\mathrm{L}}$, Low $\eta$ \\
\hline SWPF & & - & $25-47$ & Low $\eta$ \\
\hline
\end{tabular}

\subsubsection{Sludge Batch 13 (SB13)}

Four frits were identified as optimal for SB13; these provide operating windows from $25 \% \mathrm{WL}$ to at least $48 \%$ or $49 \%$ WL for both sludge-only and SWPF-based nominal projections (see Table 6). As with SB12, upper WLs are limited by predictions of $\mathrm{T}_{\mathrm{L}}$, nepheline formation, and/or low $\eta$. The trend of optimal operating windows resulting from lower $\mathrm{B}_{2} \mathrm{O}_{3}$ containing frits continues for this sludge batch. The higher $\mathrm{Li}_{2} \mathrm{O}$ contents $(5-7 \mathrm{wt} \%)$ in the four optimal frits minimize concerns of $\mathrm{T}_{\mathrm{L}}$ model applicability (via 
contribution from the frit oxides). At the upper WLs, predictions of $\mathrm{T}_{\mathrm{L}}$, nepheline formation, and/or low $\eta$ limit access to higher WLs.

Table 6. “Optimal” Frits for SB13

\begin{tabular}{|c|c|c|c|c|}
\hline Sludge & $\begin{array}{c}\text { Frit } \\
\text { (B,Li,Na,Si) }\end{array}$ & $\begin{array}{c}\text { Lower } \\
\text { Constraint }\end{array}$ & $\begin{array}{c}\text { Projected Window } \\
\text { (WL) }\end{array}$ & $\begin{array}{c}\text { Upper } \\
\text { Constraint(s) }\end{array}$ \\
\hline SO & \multirow[t]{2}{*}{$8,6,10.76$} & - & $25-48$ & $\mathrm{~T}_{\mathrm{L}}$ \\
\hline SWPF & & - & $25-49$ & Neph \\
\hline SO & \multirow[t]{2}{*}{$9,6,10,75$} & - & $25-48$ & $T_{L}$, Low $\eta$, Neph \\
\hline SWPF & & - & $25-48$ & Low $\eta$ \\
\hline SO & \multirow[t]{2}{*}{$8,5,11,76$} & - & $25-48$ & $\mathrm{~T}_{\mathrm{L}}, \mathrm{Neph}$ \\
\hline SWPF & & - & $25-49$ & Neph \\
\hline SO & \multirow[t]{2}{*}{$8,7,9,76$} & - & $25-48$ & $\mathrm{~T}_{\mathrm{L}}$, Low $\eta$ \\
\hline SWPF & & - & $25-48$ & Low $\eta$ \\
\hline
\end{tabular}

\subsubsection{Sludge Batch 14 (SB14)}

Eight frits were identified as optimal for SB14; these provide operating windows from $25 \%$ WL to at least $48 \%$ or $50 \%$ WL for both sludge-only and SWPF-based nominal projections. Table 7 summarizes the results for five of the eight (again spanning the minimum and maximum $\mathrm{B}_{2} \mathrm{O}_{3}$ contents in frit found as "optimal"). It is noted that for the " $8,5,11,76$ " frit, no limiting constraint was found at $50 \%$ WL, with SWPF included which was the maximum WL evaluated during the Nominal Stage MAR assessment. Although no constraint was identified at $50 \%$, maximum WLs are anticipated to be on the order of 51 or $52 \%$. Maximum operating windows are once again provided by the lower $\mathrm{B}_{2} \mathrm{O}_{3}$ containing frits ( 8 to 10 wt \%). The higher $\mathrm{Li}_{2} \mathrm{O}$ contents $(5-6 \mathrm{wt} \%)$ in the four optimal frits minimize concerns of $\mathrm{T}_{\mathrm{L}}$ model applicability.

Table 7. “Optimal” Frits for SB14

\begin{tabular}{|c|c|c|c|c|}
\hline Sludge & $\begin{array}{c}\text { Frit } \\
\text { (B,Li,Na,Si) }\end{array}$ & $\begin{array}{c}\text { Lower } \\
\text { Constraint }\end{array}$ & $\begin{array}{c}\text { Projected Window } \\
\text { (WL) }\end{array}$ & $\begin{array}{c}\text { Upper } \\
\text { Constraint(s) } \\
\end{array}$ \\
\hline SO & \multirow[t]{2}{*}{$8,6,10.76$} & - & $25-48$ & $\mathrm{~T}_{\mathrm{L}}$ \\
\hline SWPF & & - & $25-49$ & Low $\eta$ \\
\hline SO & \multirow[t]{2}{*}{$9,6,10,75$} & - & $25-48$ & $\mathrm{~T}_{\mathrm{L}}$, Low $\eta$ \\
\hline SWPF & & - & $25-48$ & Low $\eta$ \\
\hline SO & \multirow[t]{2}{*}{$8,5,11,76$} & - & $25-48$ & $\mathrm{~T}_{\mathrm{L}}$ \\
\hline SWPF & & - & $25-50^{*}$ & - \\
\hline SO & \multirow[t]{2}{*}{$9,5,11,75$} & - & $25-48$ & $\mathrm{~T}_{\mathrm{L}}, \mathrm{Neph}$ \\
\hline SWPF & & - & $25-49$ & Neph \\
\hline SO & \multirow[t]{2}{*}{$10,5,11,74$} & - & $25-48$ & $\mathrm{~T}_{\mathrm{L}}$, Low $\eta$, Neph \\
\hline SWPF & & - & $25-48$ & Low $\eta$ \\
\hline
\end{tabular}

\footnotetext{
${ }^{*}$ Maximum not determined given assessment covered $25-50 \%$, but not expected to be much higher than $50 \%$ (if higher at all).
} 


\subsubsection{Sludge Batch 15 (SB15)}

Based on the Nominal Stage MAR results, two frits were identified as optimal for SB15; these provide operating windows of at least as low as $29 \%$ WL up to $49 \%$ WL for both sludge-only and SWPF-based projections. As with all previous systems, the $\mathrm{B}_{2} \mathrm{O}_{3}$ contents of these optimal frits are relatively low at 8 wt $\%$. The $\mathrm{Li}_{2} \mathrm{O}$ concentrations are also relatively low (3 or 4 wt \%) and may result in $\mathrm{T}_{\mathrm{L}}$ model applicability concerns over a portion of the WL interval being assessed.

Table 8. “Optimal” Frits for SB15

\begin{tabular}{|c|c|c|c|c|}
\hline Sludge & $\begin{array}{c}\text { Frit } \\
\text { (B,Li,Na,Si) }\end{array}$ & $\begin{array}{c}\text { Lower } \\
\text { Constraint }\end{array}$ & $\begin{array}{c}\text { Projected Window } \\
\text { (WL) }\end{array}$ & $\begin{array}{c}\text { Upper } \\
\text { Constraint(s) } \\
\end{array}$ \\
\hline SO & \multirow[t]{2}{*}{$8,3,13,76$} & High $\eta$ & $28-49$ & $\mathrm{~T}_{\mathrm{L}}, \mathrm{Neph}$ \\
\hline SWPF & & High $\eta$ & $29-49$ & Neph \\
\hline SO & \multirow[t]{2}{*}{$8,4,12,76$} & High $\eta$ & $26-49$ & $\mathrm{~T}_{\mathrm{L}}$, Low $\eta$ \\
\hline SWPF & & $\operatorname{High} \eta$ & $26-49$ & Low $\eta$ \\
\hline
\end{tabular}

\subsubsection{Sludge Batch 16 (SB16)}

Five frits were identified as optimal for SB16; these provide operating windows from at least as low as $30 \% \mathrm{WL}$ up to $48 \%$ or $50 \% \mathrm{WL}$. Table 9 summarizes the results for three of the five frits (again spanning the minimum and maximum $\mathrm{B}_{2} \mathrm{O}_{3}$ contents in frits identified as optimal). It is noted that for the " $8,3,12,77$ " frit, no constraint was found at $50 \%$ WL (the maximum WL evaluated) with SWPF. Although no constraint was identified at $50 \%$, maximum WLs are anticipated to be on the order of 51 or $52 \%$. Maximum operating windows are once again provided by the lower $\mathrm{B}_{2} \mathrm{O}_{3}$ containing frits $(10 \%$ or less). The low $\mathrm{Li}_{2} \mathrm{O}$ contents $(3-4 \mathrm{wt} \%$ (not shown in Table 9)) in the optimal frits do result in concerns of $\mathrm{T}_{\mathrm{L}}$ model applicability over WLs of interest in this study.

Table 9. “Optimal” Frits for SB16

\begin{tabular}{|c|c|c|c|c|}
\hline Sludge & $\begin{array}{c}\text { Frit } \\
(\mathrm{B}, \mathrm{Li}, \mathrm{Na}, \mathrm{Si})\end{array}$ & $\begin{array}{c}\text { Lower } \\
\text { Constraint }\end{array}$ & $\begin{array}{c}\text { Projected Window } \\
\text { (WL) }\end{array}$ & $\begin{array}{c}\text { Upper } \\
\text { Constraint(s) }\end{array}$ \\
\hline SO & \multirow[t]{2}{*}{$8,3,12,77$} & High $\eta$ & $30-48$ & $\mathrm{~T}_{\mathrm{L}}$ \\
\hline SWPF & & High $\eta$ & $30-50^{*}$ & - \\
\hline SO & \multirow[t]{2}{*}{$9,3,12,76$} & High $\eta$ & $28-48$ & $T_{L}$ \\
\hline SWPF & & High $\eta$ & $28-49$ & Low $\eta$, Neph \\
\hline SO & \multirow[t]{2}{*}{$10,3,12,75$} & High $\eta$ & $26-48$ & $\mathrm{~T}_{\mathrm{L}}$, Low $\eta$, Neph \\
\hline SWPF & & High $\eta$ & $26-48$ & Low $\eta$ \\
\hline
\end{tabular}

\footnotetext{
${ }^{*}$ Maximum not determined given assessment covered $25-50 \%$, but not expected to be much higher than $50 \%$ (if higher at all).
} 


\subsubsection{Sludge Batch 17 (SB17)}

Three frits were identified as optimal for SB17; these provide operating windows from at least as low as $30 \% \mathrm{WL}$ up to $47 \%$ or $48 \% \mathrm{WL}$ (see Table 10 ). Maximum operating windows are once again provided by the lower $\mathrm{B}_{2} \mathrm{O}_{3}$ containing frits $\left(9 \%\right.$ or less). The low $\mathrm{Li}_{2} \mathrm{O}$ contents $(2-3 \mathrm{wt} \%)$ in the optimal frits do provide some concern of the applicability of the $\mathrm{T}_{\mathrm{L}}$ model over WLs of interest in this study.

Table 10. “Optimal” Frits for SB17

\begin{tabular}{|c|c|c|c|c|}
\hline Sludge & $\begin{array}{c}\text { Frit } \\
\text { (B,Li,Na,Si) }\end{array}$ & $\begin{array}{c}\text { Lower } \\
\text { Constraint }\end{array}$ & $\begin{array}{c}\text { Projected Window } \\
\text { (WL) }\end{array}$ & $\begin{array}{c}\text { Upper } \\
\text { Constraint(s) } \\
\end{array}$ \\
\hline SO & \multirow[t]{2}{*}{$8,2,14,76$} & High $\eta$ & $29-47$ & Neph \\
\hline SWPF & & High $\eta$ & $29-47$ & Neph \\
\hline SO & \multirow[t]{2}{*}{$8,3,13,76$} & High $\eta$ & $26-47$ & Low $\eta$ \\
\hline SWPF & & $\operatorname{High} \eta$ & $27-48$ & Low $\eta$, Neph \\
\hline SO & \multirow[t]{2}{*}{$9,2,13,76$} & High $\eta$ & $30-47$ & $\mathrm{~T}_{\mathrm{L}}$ \\
\hline SWPF & & High $\eta$ & $30-48$ & Neph \\
\hline
\end{tabular}

\subsection{High-Level Summary: "Optimal” Frits for Each Sludge Batch}

Based on the results of the Nominal Stage assessments only of the SB9 through SB17 projections, projected operating windows of at least as low as 30\% with upper WLs exceeding 46\% WL are achievable with current PCCS models for all future sludge batches. These operating windows are encouraging from the perspective of meeting the future contractual WL obligations of $40 \%$. That being said, there were two compositional concerns flagged as a result of the Nominal Stage assessment. The two compositional flags that surfaced were associated with the $\mathrm{B}_{2} \mathrm{O}_{3}$ and $\mathrm{Li}_{2} \mathrm{O}$ contents of the optimal frits for most of the future sludge batches. With respect to the $\mathrm{B}_{2} \mathrm{O}_{3}$ contents, all of the optimal frits identified in this study had $\mathrm{B}_{2} \mathrm{O}_{3}$ concentrations of $10 \mathrm{wt} \%$ or less - even though the upper $\mathrm{B}_{2} \mathrm{O}_{3}$ value of the frit array was $20 \%$. If higher $\mathrm{B}_{2} \mathrm{O}_{3}$ contents in frits are desired, then access to maximum WLs is less likely. In addition, if lower $\mathrm{B}_{2} \mathrm{O}_{3}$ frits are used to process future sludge batches at higher WLs, DWPF should monitor the projected $\mathrm{B}_{2} \mathrm{O}_{3}$ concentrations in glass to ensure that there are no perceived issues with the production of a non-borosilicate glass. The second compositional flag was associated with low $\mathrm{Li}_{2} \mathrm{O}$ contents in some of the optimal frits. Although there is no requirement for a minimum $\mathrm{Li}_{2} \mathrm{O}$ content (or for that matter the inclusion of $\mathrm{Li}_{2} \mathrm{O}$ in the frit), the relatively low concentration does cause some concern over the applicability of at least the $T_{L}$ model to the glass compositional regions being presented based on the optimal frits.

Based on these two compositional flags, the authors were interested in the potential use of higher $\mathrm{B}_{2} \mathrm{O}_{3}$ containing frits assuming they are desired (e.g., for melt rate purposes) or required to ensure a borosilicate glass is produced. If desired or required, what is the impact on the projected operating windows (particularly with respect to the upper or maximum WL that could be achieved) if higher $\mathrm{B}_{2} \mathrm{O}_{3}$ frits are used? Could DWPF still meet contractual WL obligations with a less optimal system in terms of maximum upper WLs? This issue is addressed in the following section.

With respect to lower $\mathrm{Li}_{2} \mathrm{O}$ concentrations, there are potential advantages and disadvantages to these types of frit. Lower $\mathrm{Li}_{2} \mathrm{O}$ contents in the frit should reduce overall frit production costs as sources of $\mathrm{Li}_{2} \mathrm{O}$ are typically among the most expensive of the raw materials. However, higher $\mathrm{Li}_{2} \mathrm{O}$ concentrations have 
been shown to improve $\mathrm{SO}_{4}$ retention or solubility criterion. Therefore, if changes to washing or blending strategies increase the projected $\mathrm{SO}_{4}$ concentration in sludge (relative to their current projected values), then higher $\mathrm{Li}_{2} \mathrm{O}$ containing frits may be desired. What is the impact of the lower $\mathrm{Li}_{2} \mathrm{O}$ containing glasses on the applicability of the $T_{L}$ model? While all of these questions or concerns need to be considered as any path forward is developed, they are not discussed further in this study.

\subsection{Potential for Higher $\mathrm{B}_{2} \underline{\mathrm{O}}_{3}$ Containing Frits}

As previously mentioned, all of the optimal frits had $\mathrm{B}_{2} \mathrm{O}_{3}$ contents between 8 and $10 \mathrm{wt} \%$ even though the maximum $\mathrm{B}_{2} \mathrm{O}_{3}$ concentration in the frit array was $20 \mathrm{wt} \%$. A detailed review of the MAR results suggests that higher $\mathrm{B}_{2} \mathrm{O}_{3}$ containing frits are available that still meet the definition of an acceptable processing window (at least as low as $30 \%$ to at least as high as $45 \% \mathrm{WL}$ ). For example, $\mathrm{B}_{2} \mathrm{O}_{3}$ contents in frit range from 12 to $17 \%$ for specific sludge batches that provide access to upper WLs of $45 \%$ WL or higher. Although these frits meet the definition of an acceptable window, they are not considered optimal in the sense that they did not provide access to the maximum upper WL.

Based on the more detailed review of the MAR results, the general trend that emerges is one of a decreasing operating window size with an increase in frit $\mathrm{B}_{2} \mathrm{O}_{3}$ concentration. To avoid having this latter statement being taken out of context, the magnitude of this trend needs to be clarified. Table 11 provides insight into this latter statement. For example, consider the two frits ("10,4,8,78" and "16,2,9,73") shown in Table 11 for SB9 (sludge-only and SWPF). Using the frit with $10 \mathrm{wt} \% \mathrm{~B}_{2} \mathrm{O}_{3}(10,4,8,78)$, the projected operating windows for sludge-only and SWPF are 30-47 and 30-48\% WL, respectively. As the $\mathrm{B}_{2} \mathrm{O}_{3}$ content increases to $16 \mathrm{wt} \%$, the projected operating windows are only slightly reduced for sludge-only and SWPF at $27-45$ and $27-46 \% \mathrm{WL}$, respectively. These windows are still classified as acceptable using the pre-defined metrics for this study. However, the question remains as to the impact of applied variation on the overall projected operating windows for these higher $\mathrm{B}_{2} \mathrm{O}_{3}$-based systems. For example, the small advantage of a lower $\mathrm{B}_{2} \mathrm{O}_{3}$ containing frit with respect to the maximum achievable WL based on the Nominal Stage assessment may be needed to ensure acceptability of the operating windows (to include the targeted WL of interest) once variation is applied. That is, the 1 or $2 \mathrm{WL}$ points gained by use of a low $\mathrm{B}_{2} \mathrm{O}_{3}$ frit may be extremely beneficial (if not required) to ensure all of the extreme vertices (EVs) can be processed over a WL interval of interest to DWPF (one including the future contractual WL of $40 \%$ ) once sludge variation is applied.

Setting this latter unknown aside, frits with $\mathrm{B}_{2} \mathrm{O}_{3}$ contents between 12 and 17 wt $\%$ are available to provide access to minimum upper WLs of $45 \%$ for all sludge-only and SWPF-based nominal projections. Therefore, if higher $\mathrm{B}_{2} \mathrm{O}_{3}$ concentrations are desired or required, there are options for consideration with the recognition that access to upper WLs may be more restricted based on current model predictions. 
Table 11. Impact of Increasing $\mathrm{B}_{2} \mathrm{O}_{3}$ and $\mathrm{Li}_{2} \mathrm{O}$ Contents in Frit on the Projected Operating Windows.

\begin{tabular}{|c|c|c|c|}
\hline $\begin{array}{l}\text { Sludge } \\
\text { Batch }\end{array}$ & $\begin{array}{l}\text { Sludge } \\
\text { Option }\end{array}$ & $\begin{array}{l}\text { Frit (B,Li,Na,Si) } \\
\text { (B Min (10) to } \\
\text { Max range with } \\
\text { 45\% WL min) }\end{array}$ & $\begin{array}{l}\text { Projected } \\
\text { Window } \\
\text { (WL) }\end{array}$ \\
\hline \multirow[t]{4}{*}{ SB9 } & $\mathrm{SO}$ & \multirow[t]{2}{*}{$10,4,8,78$} & $30-47$ \\
\hline & SWPF & & $30-48$ \\
\hline & $\mathrm{SO}$ & \multirow[t]{2}{*}{$16,2,9,73$} & $27-45$ \\
\hline & SWPF & & $27-46$ \\
\hline \multirow[t]{4}{*}{ SB10 } & $\mathrm{SO}$ & \multirow[t]{2}{*}{$10,2,12,76$} & $29-47$ \\
\hline & SWPF & & $29-47$ \\
\hline & $\mathrm{SO}$ & \multirow[t]{2}{*}{$13,2,11,74$} & $26-45$ \\
\hline & SWPF & & $27-46$ \\
\hline \multirow[t]{4}{*}{ SB11 } & $\mathrm{SO}$ & \multirow[t]{2}{*}{$10,2,13,75$} & $27-45$ \\
\hline & SWPF & & $27-48$ \\
\hline & $\mathrm{SO}$ & \multirow[t]{2}{*}{$12,2,13,73$} & $25-45$ \\
\hline & SWPF & & $25-45$ \\
\hline \multirow[t]{4}{*}{ SB12 } & SO & \multirow[t]{2}{*}{$10,6,9,75$} & $25-46$ \\
\hline & SWPF & & $25-48$ \\
\hline & SO & \multirow[t]{2}{*}{$14,3,11,72$} & $25-45$ \\
\hline & SWPF & & $25-45$ \\
\hline \multirow[t]{4}{*}{ SB13 } & $\mathrm{SO}$ & \multirow[t]{2}{*}{$10,5,10,74$} & $25-47$ \\
\hline & SWPF & & $25-48$ \\
\hline & $\mathrm{SO}$ & \multirow[t]{2}{*}{$17,3,11,69$} & $25-45$ \\
\hline & SWPF & & $25-45$ \\
\hline \multirow[t]{4}{*}{ SB14 } & $\mathrm{SO}$ & \multirow[t]{2}{*}{$10,4,11,75$} & $27-47$ \\
\hline & SWPF & & $27-49$ \\
\hline & $\mathrm{SO}$ & \multirow[t]{2}{*}{$17,3,11,69$} & $25-45$ \\
\hline & SWPF & & $25-45$ \\
\hline \multirow[t]{4}{*}{ SB15 } & $\mathrm{SO}$ & \multirow[t]{2}{*}{$10,2,13,75$} & $30-48$ \\
\hline & SWPF & & $30-49$ \\
\hline & $\mathrm{SO}$ & \multirow[t]{2}{*}{$16,3,10,71$} & $25-45$ \\
\hline & SWPF & & $25-45$ \\
\hline \multirow[t]{4}{*}{ SB16 } & $\mathrm{SO}$ & \multirow[t]{2}{*}{$10,3,11,76$} & $29-47$ \\
\hline & SWPF & & $29-49$ \\
\hline & $\mathrm{SO}$ & \multirow[t]{2}{*}{$16,2,11,71$} & $25-45$ \\
\hline & SWPF & & $25-45$ \\
\hline \multirow[t]{4}{*}{ SB17 } & SO & \multirow[t]{2}{*}{$10,2,13,75$} & $28-46$ \\
\hline & SWPF & & $28-48$ \\
\hline & $\mathrm{SO}$ & \multirow[t]{2}{*}{$14,2,12,72$} & $25-45$ \\
\hline & SWPF & & $25-45$ \\
\hline
\end{tabular}


As previously mentioned, there is concern over the lower $\mathrm{B}_{2} \mathrm{O}_{3}$ and/or $\mathrm{Li}_{2} \mathrm{O}$ contents of the optimal frits and the translation of these oxide contributions into glass relative to the model development and/or validation ranges (especially for the $\mathrm{T}_{\mathrm{L}}$ model). With concerns for $\mathrm{B}_{2} \mathrm{O}_{3}$ and $\mathrm{Li}_{2} \mathrm{O}$ contributions coming from the frit (at least based on the Revision 16 projections), model applicability is also a concern at higher WLs for those oxides associated with sludge. For example, at higher WLs are the $\mathrm{Fe}_{2} \mathrm{O}_{3}, \mathrm{NiO}, \mathrm{Cr}_{2} \mathrm{O}_{3}$, $\mathrm{MnO}$, and $\mathrm{Al}_{2} \mathrm{O}_{3}$ values (to name a few) within the development or validation ranges for the PCCS models? If not, what is the impact of using these models to reflect projected operating windows which serve as the basis for judging whether or not contractual WLs can be met in the future? These items are discussed in the next section (Section 6.4).

\subsection{Model Development and High WL Compositional Gaps}

In addition to the potential compositional issues associated with low $\mathrm{Li}_{2} \mathrm{O}$ and/or $\mathrm{B}_{2} \mathrm{O}_{3}$ contents for these glass systems resulting from frits that would provide access to WLs in excess of $45 \%$, one also has to consider compositional gaps or differences relative to model development or validation ranges for these glass systems due to the sludge space. That is, at these higher WLs, are there sludge components that will ultimately have concentrations in glass that fall outside of the model development or validation intervals of the current PCCS models? To evaluate this possibility, the nominal sludge-only compositions (for SB9 through SB17) were used to calculate the projected concentrations of some of the major oxides in glass at 40, 45, and 50\% WL. ${ }^{*}$ These projected concentrations were then compared to their respective oxide intervals over which the $T_{L}$ model had been developed. ${ }^{6}$ The results are shown in Table 12. It should be noted that the sludge-only options were used given introduction of $\mathrm{TiO}_{2}$ from SWPF essentially dilutes the other sludge components and the authors wanted to assess a potentially bounding situation. The potential for $\mathrm{TiO}_{2}$ to exceed the current $2.0 \mathrm{wt} \%$ PCCS limit was performed in a separate calculation which is discussed below. It should also be noted that comparisons to model development intervals are only being made with respect to the $\mathrm{T}_{\mathrm{L}}$ model.

The $\mathrm{Al}_{2} \mathrm{O}_{3}, \mathrm{CaO}, \mathrm{Cr}_{2} \mathrm{O}_{3}, \mathrm{Fe}_{2} \mathrm{O}_{3}, \mathrm{MgO}, \mathrm{MnO}, \mathrm{NiO}$, and $\mathrm{U}_{3} \mathrm{O}_{8}$ values projected at $40 \%$, 45, and 50\% $\mathrm{WL}$ for each of the sludge-only nominal compositions are shown in Table 12. For example, for $\mathrm{SB} 9$, the $\mathrm{Al}_{2} \mathrm{O}_{3}$ and $\mathrm{Fe}_{2} \mathrm{O}_{3}$ contents in glass are projected to be 5.089 and $15.346 \mathrm{wt} \%$, respectively at $40 \% \mathrm{WL}$. These calculations assume that the frit composition is based on the four major oxides $\left(\mathrm{B}_{2} \mathrm{O}_{3}, \mathrm{Li}_{2} \mathrm{O}, \mathrm{Na}_{2} \mathrm{O}\right.$, and $\mathrm{SiO}_{2}$ ) and does not include oxides such as $\mathrm{Fe}_{2} \mathrm{O}_{3}, \mathrm{Al}_{2} \mathrm{O}_{3}$, or $\mathrm{MgO}$ which are assumed to be contributed only by the sludge. The shaded cells in Table 12 (labeled "Min" and "Max") provide the minimum and maximum values for each oxide over the 9 sludge batches for each of the three assumed WLs $(40,45$, and $50 \% \mathrm{WL}$ ). The rows labeled " $\mathrm{T}_{\mathrm{L}}$ Model Min" and " $\mathrm{T}_{\mathrm{L}}$ Model Max" provide the $\mathrm{T}_{\mathrm{L}}$ model development intervals as defined by Brown et al. ${ }^{6}$ for the respective oxides. Note that the sludge oxides listed in Table 12 are not all inclusive. That is, there are other sludge components that would contribute to the overall glass composition that are not shown in the table (e.g., $\mathrm{K}_{2} \mathrm{O}, \mathrm{ZrO}_{2}, \mathrm{Na}_{2} \mathrm{O}, \mathrm{SiO}_{2}$ ). With the "Min" and "Max" values for each major oxide defined, a comparison can be made to identify those oxide concentrations that are projected to be outside the $\mathrm{T}_{\mathrm{L}}$ model development intervals. Those values are highlighted in red in Table 12.

At $40 \% \mathrm{WL}$, all of the projected oxide concentrations in glass are within the $\mathrm{T}_{\mathrm{L}}$ model development intervals as defined by Brown et al. ${ }^{6}$ with the exception of $\mathrm{MgO}$ (highlighted in red). The projected $\mathrm{MgO}$ concentrations in glass at $40 \% \mathrm{WL}$ across all of sludge batches are below those used in the development of the $T_{L}$ model. This is likely due to the fact that initial DWPF frits (Frit 200 and Frit 202) contained $\mathrm{MgO}$ and glasses based on these frit were the major source of data used to develop the model while the

\footnotetext{
${ }^{*}$ Although the future contractual WL is nominally $40 \% \mathrm{WL}$, higher WLs may be required to ensure the nominal $40 \% \mathrm{WL}$ is attained.
} 
frit grid used in this study only included $\mathrm{B}_{2} \mathrm{O}_{3}, \mathrm{Li}_{2} \mathrm{O}, \mathrm{Na}_{2} \mathrm{O}$, and $\mathrm{SiO}_{2}$. The fact that $\mathrm{MgO}$ concentrations in the projected glasses are lower than the model development intervals should have very little impact (if any) on using the current $T_{L}$ model to make predictions about future operations. Therefore, one would anticipate that the $T_{L}$ model is applicable to those glass compositional regions being projected for the eighteen sludge batches with respect to these major sludge oxides at $40 \% \mathrm{WL}$.

As the WL increases, there is an increase in the number of oxides that exceed the upper value over which the $\mathrm{T}_{\mathrm{L}}$ model was developed. Although this is the case, the number of oxides exceeding their $\mathrm{T}_{\mathrm{L}}$ model development intervals is rather limited. At $45 \% \mathrm{WL}$, the projected $\mathrm{Fe}_{2} \mathrm{O}_{3}$ and $\mathrm{MgO}$ values exceed model development intervals. For example, at $45 \% \mathrm{WL}$, the $\mathrm{Fe}_{2} \mathrm{O}_{3}$ concentration for $\mathrm{SB} 11(18.440 \mathrm{wt} \%$ in glass) is projected to be outside the upper $\mathrm{T}_{\mathrm{L}}$ model development concentration of $17.6 \mathrm{wt} \%$. At $50 \%$ WL, $\mathrm{MnO}$ and $\mathrm{U}_{3} \mathrm{O}_{8}$ in addition to $\mathrm{Fe}_{2} \mathrm{O}_{3}$ and $\mathrm{MgO}$ (below its limit) are also flagged as being outside the $\mathrm{T}_{\mathrm{L}}$ model development intervals. As with the lower $\mathrm{Li}_{2} \mathrm{O}$ issue, there appear to be additional compositional regions (higher $\mathrm{MnO}, \mathrm{Fe}_{2} \mathrm{O}_{3}$, and $\mathrm{U}_{3} \mathrm{O}_{8}$ and lower $\mathrm{MgO}$ ) which need to be further explored if higher WLs are to be targeted. 
Table 12. Comparison of Projected Oxide Contents in Glass at Various WLs to the $\mathbf{T}_{\mathrm{L}}$ Model Development Ranges.

\begin{tabular}{|c|c|c|c|c|c|c|c|c|}
\hline $40 \% \mathrm{WL}$ & $\mathbf{A l}_{2} \mathbf{O}_{3}$ & $\mathrm{CaO}$ & $\mathrm{Cr}_{2} \mathrm{O}_{3}$ & $\overline{F^{2} \mathbf{e}_{2} \mathbf{O}_{3}}$ & MgO & MnO & NiO & $\overline{\mathrm{U}_{3} \mathrm{O}_{8}}$ \\
\hline SB9 - Blend - SO & 5.089 & 1.275 & 0.116 & 15.346 & 0.197 & 3.273 & 0.403 & 0.607 \\
\hline SB10 - Blend - SO & 5.132 & 1.377 & 0.115 & 16.378 & 0.261 & 2.694 & 0.251 & 0.418 \\
\hline SB11 - Blend - SO & 6.051 & 1.217 & 0.173 & 16.391 & 0.262 & 1.480 & 0.151 & 0.233 \\
\hline SB12 - Blend - SO & 7.814 & 1.323 & 0.173 & 14.246 & 0.196 & 1.678 & 0.150 & 1.022 \\
\hline SB13 - Blend - SO & 7.162 & 1.215 & 0.173 & 12.532 & 0.131 & 1.275 & 0.502 & 3.911 \\
\hline SB14 - Blend - SO & 6.655 & 1.163 & 0.174 & 11.938 & 0.131 & 1.073 & 0.655 & 5.367 \\
\hline SB15 - Blend - SO & 5.527 & 1.106 & 0.173 & 11.869 & 0.131 & 1.174 & 0.755 & 7.132 \\
\hline SB16 - Blend - SO & 5.753 & 1.162 & 0.116 & 13.681 & 0.131 & 0.970 & 0.604 & 6.062 \\
\hline SB17 - Blend - SO & 5.883 & 1.158 & 0.115 & 14.481 & 0.196 & 0.865 & 0.552 & 5.484 \\
\hline $\operatorname{Min}(40 \% \mathrm{WL})$ & 5.089 & 1.106 & 0.115 & 11.869 & 0.131 & 0.865 & 0.150 & 0.233 \\
\hline Max (40\% WL) & 7.814 & 1.377 & 0.174 & 16.391 & 0.262 & 3.273 & 0.755 & 7.132 \\
\hline $\mathrm{T}_{\mathrm{L}}$ Model Min & 0.990 & 0.305 & 0.000 & 3.452 & 0.470 & 0.739 & 0.038 & 0.000 \\
\hline $\mathrm{T}_{\mathrm{L}}$ Model Max & 14.162 & 2.007 & 0.301 & 17.600 & 2.650 & 3.250 & 3.045 & 5.138 \\
\hline $45 \% \mathrm{WL}$ & $\mathbf{A l}_{2} \mathbf{O}_{3}$ & $\mathrm{CaO}$ & $\mathrm{Cr}_{2} \mathrm{O}_{3}$ & $\mathrm{Fe}_{2} \mathrm{O}_{3}$ & MgO & MnO & NiO & $\mathbf{U}_{3} \mathbf{O}_{8}$ \\
\hline SB9 - Blend - SO & 5.725 & 1.434 & 0.130 & 17.264 & 0.222 & 3.682 & 0.454 & 0.683 \\
\hline SB10 - Blend - SO & 5.774 & 1.549 & 0.129 & 18.425 & 0.294 & 3.031 & 0.282 & 0.470 \\
\hline SB11 - Blend - SO & 6.807 & 1.369 & 0.195 & 18.440 & 0.295 & 1.665 & 0.170 & 0.262 \\
\hline SB12 - Blend - SO & 8.790 & 1.488 & 0.194 & 16.026 & 0.220 & 1.888 & 0.169 & 1.149 \\
\hline SB13 - Blend - SO & 8.058 & 1.367 & 0.195 & 14.099 & 0.147 & 1.434 & 0.565 & 4.400 \\
\hline SB14 - Blend - SO & 7.487 & 1.308 & 0.195 & 13.430 & 0.148 & 1.207 & 0.736 & 6.037 \\
\hline SB15 - Blend - SO & 6.218 & 1.245 & 0.195 & 13.352 & 0.147 & 1.321 & 0.849 & 8.024 \\
\hline SB16 - Blend - SO & 6.472 & 1.307 & 0.130 & 15.391 & 0.148 & 1.091 & 0.679 & 6.819 \\
\hline SB17 - Blend - SO & 6.618 & 1.303 & 0.130 & 16.291 & 0.221 & 0.973 & 0.621 & 6.169 \\
\hline $\operatorname{Min}(45 \% \mathrm{WL})$ & 5.725 & 1.245 & 0.129 & 13.352 & 0.147 & 0.973 & 0.169 & 0.262 \\
\hline Max (45\% WL) & 8.790 & 1.549 & 0.195 & 18.440 & 0.295 & 3.682 & 0.849 & 8.024 \\
\hline $\mathrm{T}_{\mathrm{L}}$ Model Min & 0.990 & 0.305 & 0.000 & 3.452 & 0.470 & 0.739 & 0.038 & 0.000 \\
\hline $\mathrm{T}_{\mathrm{L}}$ Model Max & 14.162 & 2.007 & 0.301 & 17.600 & 2.650 & 3.250 & 3.045 & 5.138 \\
\hline $50 \% \mathrm{WL}$ & $\mathbf{A l}_{2} \mathbf{O}_{3}$ & $\mathrm{CaO}$ & $\mathrm{Cr}_{2} \mathrm{O}_{3}$ & $\mathrm{Fe}_{2} \mathrm{O}_{3}$ & MgO & MnO & $\mathrm{NiO}$ & $\mathrm{U}_{3} \mathrm{O}_{8}$ \\
\hline SB9 - Blend - SO & 6.361 & 1.593 & 0.145 & 19.182 & 0.246 & 4.091 & 0.504 & 0.759 \\
\hline SB10 - Blend - SO & 6.415 & 1.721 & 0.144 & 20.472 & 0.326 & 3.367 & 0.313 & 0.522 \\
\hline SB11 - Blend - SO & 7.563 & 1.521 & 0.217 & 20.489 & 0.328 & 1.850 & 0.189 & 0.291 \\
\hline SB12 - Blend - SO & 9.767 & 1.653 & 0.216 & 17.807 & 0.245 & 2.098 & 0.188 & 1.277 \\
\hline SB13 - Blend - SO & 8.953 & 1.519 & 0.216 & 15.665 & 0.164 & 1.593 & 0.628 & 4.889 \\
\hline SB14 - Blend - SO & 8.319 & 1.453 & 0.217 & 14.922 & 0.164 & 1.341 & 0.818 & 6.708 \\
\hline SB15 - Blend - SO & 6.909 & 1.383 & 0.217 & 14.836 & 0.164 & 1.467 & 0.943 & 8.915 \\
\hline SB16 - Blend - SO & 7.191 & 1.452 & 0.144 & 17.101 & 0.164 & 1.213 & 0.755 & 7.577 \\
\hline SB17 - Blend - SO & 7.354 & 1.448 & 0.144 & 18.101 & 0.245 & 1.081 & 0.690 & 6.855 \\
\hline $\operatorname{Min}(50 \% \mathrm{WL})$ & 6.361 & 1.383 & 0.144 & 14.836 & 0.164 & 1.081 & 0.188 & 0.291 \\
\hline $\operatorname{Max}(50 \% \mathrm{WL})$ & 9.767 & 1.721 & 0.217 & 20.489 & 0.328 & 4.091 & 0.943 & 8.915 \\
\hline $\mathrm{T}_{\mathrm{L}}$ Model Min & 0.990 & 0.305 & 0.000 & 3.452 & 0.470 & 0.739 & 0.038 & 0.000 \\
\hline $\mathrm{T}_{\mathrm{L}}$ Model Max & 14.162 & 2.007 & 0.301 & 17.600 & 2.650 & 3.250 & 3.045 & 5.138 \\
\hline
\end{tabular}




\subsection{Frits that Are Robust to All Sludge Batches}

In Section 6.1, the primary focus was to identify candidate frits that were optimal for each nominal sludge batch. Although this approach provided insight not only into whether the current PCCS models would provide access to higher WLs, it also provided the opportunity to flag the compositional gaps or concerns that may need to be addressed through future experimental studies or utilization of existing data from studies in support of DWPF (or in the DWPF compositional region of interest).

In this section, the perspective with respect to frit development shifts from optimization to robustness. That is, can frits be identified that provide access to the higher WLs (or acceptable projected operating windows) for all eighteen sludge compositions (e.g., SB9 through SB17; both with and without SWPF)? An electronic search of the MAR results indicated six frits that provide operating windows of at least as low as $30 \% \mathrm{WL}$ to at least as high as $44 \% \mathrm{WL}$ for all 18 sludge compositions. Table 13 presents the compositions of these six frits (using the abbreviated nomenclature identifying the wt $\%$ of $\mathrm{B}_{2} \mathrm{O}_{3}, \mathrm{Li}_{2} \mathrm{O}$, $\mathrm{Na}_{2} \mathrm{O}$, and $\mathrm{SiO}_{2}$ as used in previous sections) along with the projected operating windows for the sludgeonly projections. In addition to the nominal frit compositions, the WL-limiting constraints are provided. Table 14 provides the projected operating windows for the SWPF-based sludges.

As previously mentioned, each of the robust frits provides a projected operating window of at least as low as $30 \% \mathrm{WL}$ up to at least as high as $44 \%$ for all 18 sludge compositions. This suggests that if DWPF were to implement one of these frits into their flowsheet, WLs of at least $44 \%$ could be accessed for all of the nominal sludge projections. For example, consider the use of a frit that contains $10 \% \mathrm{~B}_{2} \mathrm{O}_{3}, 3 \% \mathrm{Li}_{2} \mathrm{O}$, $12 \% \mathrm{Na}_{2} \mathrm{O}$, and $75 \% \mathrm{SiO}_{2}$ ("10,3,12,75") in Table 13 . For the nine sludge-only options (first column in Table 13), the upper WLs range from 44\% WL (for SB9 and SB10) to 48\% WL (for SB16) with predictions of either low viscosity (low $\eta$ ) or $T_{L}$ limiting access for all of the windows with the exception of one (SB12 where formation of nepheline limits access to WLs of $46 \% \mathrm{WL}$ and higher). When the $10 \%$ $\mathrm{B}_{2} \mathrm{O}_{3}, 3 \% \mathrm{Li}_{2} \mathrm{O}, 12 \% \mathrm{Na}_{2} \mathrm{O}$, and $75 \% \mathrm{SiO}_{2}$ frit is coupled with the SWPF-based sludge batches (Table 14), the upper WLs range from 45\% WL (for SB9 and SB10) to 49\% WL (SB15) with predictions of low $\eta$, $\mathrm{T}_{\mathrm{L}}$, or nepheline formation limiting access to higher WLs for specific sludge batch options.

A comparison of the sludge-only operating windows with their SWPF-based counterparts indicates that the addition of SWPF to the sludge-only flowsheet does not have a negative impact on the operating windows. In fact, the upper WLs either remain the same or in most cases, actually increase with the addition of SWPF. An increase in the upper WL is most apparent when the sludge-only system is $\mathrm{T}_{\mathrm{L}}$ limited and the addition of $\mathrm{Na}_{2} \mathrm{O}$ from SWPF lowers the predicted $\mathrm{T}_{\mathrm{L}}$ which provides 1 to 4 points in the upper WL that can be achieve for some systems. For example, consider the shaded cells in Table 13 and Table 14 associated with $\mathrm{SB} 12$ coupled with the $8 \% \mathrm{~B}_{2} \mathrm{O}_{3}, 6 \% \mathrm{Li}_{2} \mathrm{O}, 8 \% \mathrm{Na}_{2} \mathrm{O}$, and $78 \% \mathrm{SiO}_{2}$ frit. The projected operating window for the sludge-only system is $28-45 \% \mathrm{WL}\left(\mathrm{T}_{\mathrm{L}}\right.$ limited) while its counterpart SWPF-based system has a window of $28-49 \%$ (still $\mathrm{T}_{\mathrm{L}}$ limited).

Again, the six frits identified in Table 13 and Table 14 are robust to all of the nominal projected sludge batches from Revision 16 of the HLW System Plan. Although these frits provide operating windows of at least as low as $30 \%$ up to as least as low as $44 \% \mathrm{WL}$, the inclusion of other secondary streams is not addressed in this study, and these systems will have impacts (detrimental or positive) on the projected operating windows. In addition, if $\mathrm{SO}_{4}$ retention or melt rate becomes an issue that must be addressed through frit development efforts, the six frits provide little opportunity to make significant improvements in these factors.

The statements regarding robustness are based on the fact that the projected operating windows were computed using nominal sludge compositions and do not account for any sludge variation within a 
specific sludge batch. Although the frits demonstrate robustness across all 18 sludge compositions, when variation is applied to a specific sludge batch (e.g., $\pm 7.5 \%$ around major oxides, $\pm 0.5 \mathrm{wt} \%$ around minor oxides) one typically sees a reduction in the operating window over which a specific frit can process all of the extreme vertices (EVs) that are defined by the applied variation. The impact of this variation is addressed in the next section using a specific frit which was identified as being robust to all 18 sludge projections.

Table 13. Candidate Frits that are Robust to all Eighteen Projections (Sludge-only Options).

\begin{tabular}{|c|c|c|c|c|c|c|}
\hline $\begin{array}{l}\text { Sludge } \\
\text { Batch }\end{array}$ & $10,3,12,75$ & $11,2,13,74$ & $8,5,10,77$ & $\overline{8,6,8,78}$ & $9,4,11,76$ & $\overline{9,5,9,77}$ \\
\hline 9 & $\begin{array}{l}\mathrm{Al}_{2} \mathrm{O}_{3} \\
26-44 \\
\text { Low } \eta \\
\end{array}$ & $\begin{array}{l}\mathrm{Al}_{2} \mathrm{O}_{3} \\
26-44 \\
\text { Low } \eta \\
\end{array}$ & $\begin{array}{l}\mathrm{Al}_{2} \mathrm{O}_{3} \\
26-44 \\
\text { Low } \eta \\
\end{array}$ & $\begin{array}{l}\mathrm{Al}_{2} \mathrm{O}_{3} \\
26-45 \\
\text { Low } \eta \\
\end{array}$ & $\begin{array}{l}\mathrm{Al}_{2} \mathrm{O}_{3} \\
26-44 \\
\text { Low } \eta \\
\end{array}$ & $\begin{array}{l}\mathrm{Al}_{2} \mathrm{O}_{3} \\
26-45 \\
\text { Low } \eta\end{array}$ \\
\hline 10 & $\begin{array}{c}- \\
25-44 \\
\text { Low } \eta\end{array}$ & $\begin{array}{c}- \\
25-44 \\
\text { Low } \eta\end{array}$ & $\begin{array}{l}25-44 \\
\text { Low } \eta\end{array}$ & $\begin{array}{c}- \\
25-45 \\
\text { Low } \eta \\
\end{array}$ & $\begin{array}{l}25-44 \\
\text { Low } \eta\end{array}$ & $\begin{array}{c}- \\
25-45 \\
\text { Low } \eta\end{array}$ \\
\hline 11 & $\begin{array}{c}- \\
25-45 \\
T_{\mathrm{L}} \\
\end{array}$ & $\begin{array}{c}- \\
25-45 \\
\mathrm{~T}_{\mathrm{L}} \\
\end{array}$ & $\begin{array}{c}- \\
25-45 \\
T_{\mathrm{L}} \\
\end{array}$ & $\begin{array}{c}- \\
25-44 \\
\mathrm{~T}_{\mathrm{L}} \\
\end{array}$ & $\begin{array}{c}- \\
25-45 \\
\mathrm{~T}_{\mathrm{L}} \\
\end{array}$ & $\begin{array}{c}- \\
25-44 \\
T_{L} \\
\end{array}$ \\
\hline 12 & $\begin{array}{c}\text { High } \eta \\
29-45 \\
\text { Neph } \\
\end{array}$ & $\begin{array}{l}\text { High } \eta \\
29-44 \\
\text { Neph } \\
\end{array}$ & $\begin{array}{c}\text { High } \eta \\
28-46 \\
T_{L} \\
\end{array}$ & $\begin{array}{c}\text { High } \eta \\
28-45 \\
\mathrm{~T}_{\mathrm{L}} \\
\end{array}$ & $\begin{array}{c}\text { High } \eta \\
28-46 \\
T_{L} \\
\end{array}$ & $\begin{array}{c}\text { High } \eta \\
29-45 \\
T_{L} \\
\end{array}$ \\
\hline 13 & $\begin{array}{c}\text { High } \eta \\
30-47 \\
T_{L} \\
\end{array}$ & $\begin{array}{l}\text { High } \eta \\
30-45 \\
\text { Neph } \\
\end{array}$ & $\begin{array}{c}\text { High } \eta \\
28-47 \\
T_{\mathrm{L}} \\
\end{array}$ & $\begin{array}{c}\text { High } \eta \\
29-46 \\
\mathrm{~T}_{\mathrm{L}} \\
\end{array}$ & $\begin{array}{c}\text { High } \eta \\
29-47 \\
T_{L} \\
\end{array}$ & $\begin{array}{c}\text { High } \eta \\
30-45 \\
T_{L} \\
\end{array}$ \\
\hline 14 & $\begin{array}{c}\text { High } \eta \\
30-47 \\
T_{\mathrm{L}} \\
\end{array}$ & $\begin{array}{c}\text { High } \eta \\
30-46 \\
\text { Neph } \\
\end{array}$ & $\begin{array}{c}\text { High } \eta \\
28-47 \\
T_{L} \\
\end{array}$ & $\begin{array}{c}\text { High } \eta \\
29-46 \\
\mathrm{~T}_{\mathrm{L}} \\
\end{array}$ & $\begin{array}{c}\text { High } \eta \\
29-47 \\
T_{L} \\
\end{array}$ & $\begin{array}{c}\text { High } \eta \\
30-46 \\
\mathrm{~T}_{\mathrm{L}} \\
\end{array}$ \\
\hline 15 & $\begin{array}{c}\text { High } \eta \\
28-47 \\
T_{\mathrm{L}} \\
\end{array}$ & $\begin{array}{c}\text { High } \eta \\
28-47 \\
T_{L} \\
\end{array}$ & $\begin{array}{c}\text { High } \eta \\
26-48 \\
T_{L} \\
\end{array}$ & $\begin{array}{c}\text { High } \eta \\
27-46 \\
T_{L} \\
\end{array}$ & $\begin{array}{c}\text { High } \eta \\
27-47 \\
T_{L} \\
\end{array}$ & $\begin{array}{c}\text { High } \eta \\
28-46 \\
T_{L} \\
\end{array}$ \\
\hline 16 & $\begin{array}{l}\text { High } \eta \\
26-48 \\
\text { Low } \eta \\
\end{array}$ & $\begin{array}{l}\text { High } \eta \\
27-47 \\
\text { Neph } \\
\end{array}$ & $\begin{array}{c}- \\
25-47 \\
\text { Low } \eta\end{array}$ & $\begin{array}{c}\text { High } \eta \\
26-47 \\
T_{L} \\
\end{array}$ & $\begin{array}{l}\text { High } \eta \\
26-47 \\
\text { Low } \eta \\
\end{array}$ & $\begin{array}{c}\text { High } \eta \\
26-47 \\
T_{L} \\
\end{array}$ \\
\hline 17 & $\begin{array}{c}\text { High } \eta \\
26-46 \\
T_{\mathrm{L}} \\
\end{array}$ & $\begin{array}{c}\text { High } \eta \\
26-46 \\
T_{L} \\
\end{array}$ & $\begin{array}{c}- \\
25-46 \\
T_{L} \\
\end{array}$ & $\begin{array}{c}- \\
25-45 \\
T_{L} \\
\end{array}$ & $\begin{array}{c}- \\
25-46 \\
\mathrm{~T}_{\mathrm{L}} \\
\end{array}$ & $\begin{array}{c}\text { High } \eta \\
26-45 \\
T_{L} \\
\end{array}$ \\
\hline
\end{tabular}


Table 14. Candidate Frits that are Robust to all Eighteen Projections (SWPF-Based Options).

\begin{tabular}{|c|c|c|c|c|c|c|}
\hline $\begin{array}{l}\text { Sludge } \\
\text { Batch }\end{array}$ & $10,3,12,75$ & $11,2,13,74$ & $8,5,10,77$ & $8,6,8,78$ & $9,4,11,76$ & $9,5,9,77$ \\
\hline 9 & $\begin{array}{l}\mathrm{Al}_{2} \mathrm{O}_{3} \\
27-45 \\
\text { Low } \eta \\
\end{array}$ & $\begin{array}{l}\mathrm{Al}_{2} \mathrm{O}_{3} \\
27-45 \\
\text { Low } \eta \\
\end{array}$ & $\begin{array}{l}\mathrm{Al}_{2} \mathrm{O}_{3} \\
27-45 \\
\text { Low } \eta \\
\end{array}$ & $\begin{array}{l}\mathrm{Al}_{2} \mathrm{O}_{3} \\
27-45 \\
\text { Low } \eta \\
\end{array}$ & $\begin{array}{l}\mathrm{Al}_{2} \mathrm{O}_{3} \\
27-45 \\
\text { Low } \eta \\
\end{array}$ & $\begin{array}{l}\mathrm{Al}_{2} \mathrm{O}_{3} \\
27-45 \\
\text { Low } \eta \\
\end{array}$ \\
\hline 10 & $\begin{array}{l}\mathrm{Al}_{2} \mathrm{O}_{3} \\
26-45 \\
\text { Low } \eta \\
\end{array}$ & $\begin{array}{l}\mathrm{Al}_{2} \mathrm{O}_{3} \\
26-45 \\
\text { Low } \eta \\
\end{array}$ & $\begin{array}{l}\mathrm{Al}_{2} \mathrm{O}_{3} \\
26-45 \\
\text { Low } \eta\end{array}$ & $\begin{array}{l}\mathrm{Al}_{2} \mathrm{O}_{3} \\
26-45 \\
\text { Low } \eta\end{array}$ & $\begin{array}{l}\mathrm{Al}_{2} \mathrm{O}_{3} \\
26-45 \\
\text { Low } \eta\end{array}$ & $\begin{array}{l}\mathrm{Al}_{2} \mathrm{O}_{3} \\
26-45 \\
\text { Low } \eta \\
\end{array}$ \\
\hline 11 & $\begin{array}{c}- \\
25-47 \\
\text { Low } \eta\end{array}$ & $\begin{array}{c}- \\
25-47 \\
\text { Low } \eta\end{array}$ & $\begin{array}{c}- \\
25-46 \\
\text { Low } \eta\end{array}$ & $\begin{array}{c}- \\
25-47 \\
\text { Low } \eta\end{array}$ & $\begin{array}{c}- \\
25-47 \\
\text { Low } \eta\end{array}$ & $\begin{array}{c}- \\
25-47 \\
\text { Low } \eta \\
\end{array}$ \\
\hline 12 & $\begin{array}{c}\text { High } \eta \\
29-46 \\
\text { Neph } \\
\end{array}$ & $\begin{array}{c}\text { High } \eta \\
29-45 \\
\text { Neph } \\
\end{array}$ & $\begin{array}{l}\text { High } \eta \\
28-48 \\
\text { Neph } \\
\end{array}$ & $\begin{array}{c}\text { High } \eta \\
28-49 \\
T_{L} \\
\end{array}$ & $\begin{array}{c}\text { High } \eta \\
28-47 \\
\text { Neph } \\
\end{array}$ & $\begin{array}{c}\text { High } \eta \\
29-49 \\
\mathrm{~T}_{\mathrm{L}}, \mathrm{Neph}\end{array}$ \\
\hline 13 & $\begin{array}{c}\text { High } \eta \\
30-47 \\
\text { Neph } \\
\end{array}$ & $\begin{array}{c}\text { High } \eta \\
30-46 \\
\text { Neph } \\
\end{array}$ & $\begin{array}{c}\text { High } \eta \\
29-49 \\
T_{L} \\
\end{array}$ & $\begin{array}{c}\text { High } \eta \\
30-47 \\
T_{L} \\
\end{array}$ & $\begin{array}{c}\text { High } \eta \\
29-49 \\
T_{L}, \text { Neph }\end{array}$ & $\begin{array}{c}\text { High } \eta \\
30-48 \\
T_{L} \\
\end{array}$ \\
\hline 14 & $\begin{array}{c}\text { High } \eta \\
30-48 \\
\text { Neph } \\
\end{array}$ & $\begin{array}{c}\text { High } \eta \\
30-47 \\
\text { Neph } \\
\end{array}$ & $\begin{array}{c}\text { High } \eta \\
29-49 \\
T_{L} \\
\end{array}$ & $\begin{array}{c}\text { High } \eta \\
29-48 \\
T_{L} \\
\end{array}$ & $\begin{array}{c}\text { High } \eta \\
29-49 \\
\mathrm{~T}_{\mathrm{L}} \\
\end{array}$ & $\begin{array}{c}\text { High } \eta \\
30-48 \\
T_{L} \\
\end{array}$ \\
\hline 15 & $\begin{array}{c}\text { High } \eta \\
28-49 \\
T_{L} \\
\end{array}$ & $\begin{array}{c}\text { High } \eta \\
29-48 \\
\text { Neph } \\
\end{array}$ & $\begin{array}{c}\text { High } \eta \\
27-49 \\
T_{L} \\
\end{array}$ & $\begin{array}{c}\text { High } \eta \\
28-48 \\
T_{\mathrm{L}} \\
\end{array}$ & $\begin{array}{c}\text { High } \eta \\
27-49 \\
\mathrm{~T}_{\mathrm{L}} \\
\end{array}$ & $\begin{array}{c}\text { High } \eta \\
28-48 \\
T_{L} \\
\end{array}$ \\
\hline 16 & $\begin{array}{l}\text { High } \eta \\
26-48 \\
\text { Low } \eta\end{array}$ & $\begin{array}{c}\text { High } \eta \\
27-48 \\
\text { Low } \eta, \text { Neph }\end{array}$ & $\begin{array}{c}- \\
25-48 \\
\text { Low } \eta\end{array}$ & $\begin{array}{l}\text { High } \eta \\
26-48 \\
\text { Low } \eta\end{array}$ & $\begin{array}{l}\text { High } \eta \\
26-48 \\
\text { Low } \eta\end{array}$ & $\begin{array}{l}\text { High } \eta \\
27-48 \\
\text { Low } \eta\end{array}$ \\
\hline 17 & $\begin{array}{l}\text { High } \eta \\
26-47 \\
\text { Low } \eta \\
\end{array}$ & $\begin{array}{c}\text { High } \eta \\
26-47 \\
\text { Low } \eta, \text { Neph } \\
\end{array}$ & $\begin{array}{c}- \\
25-47 \\
\text { Low } \eta\end{array}$ & $\begin{array}{c}\text { High } \eta \\
26-47 \\
T_{L} \\
\end{array}$ & $\begin{array}{c}- \\
25-47 \\
\text { Low } \eta\end{array}$ & $\begin{array}{c}\text { High } \eta \\
26-47 \\
T_{L}\end{array}$ \\
\hline
\end{tabular}

\subsection{Variation Stage Assessment}

To support the Variation Stage assessment, compositional variation was applied to the minimum and maximum values based on sludge-only and SWPF-based projections for each oxide within each sludge batch. Based on the approach developed by Peeler and Edwards ${ }^{7}, \pm 7.5 \%$ variation was placed around the major oxides, $\pm 0.5 \mathrm{wt} \%$ was used for the minor oxides, and $\pm 0.1 \mathrm{wt} \%$ was added to $\mathrm{SO}_{4}$. All other oxides not falling into these three categories (i.e., majors, minors, or $\mathrm{SO}_{4}$ ) were averaged across all 18 sludge compositions and placed into an "Others" category. The averaged "Others" group was applied to each sludge composition. These sludge composition intervals were then used to generate extreme vertices (EVs) that bounded each sludge batch. Each set of EVs was then coupled with the $10 \% \mathrm{~B}_{2} \mathrm{O}_{3}, 3 \% \mathrm{Li}_{2} \mathrm{O}$, $12 \% \mathrm{Na}_{2} \mathrm{O}$, and $75 \% \mathrm{SiO}_{2}$ frit over an interval of $25-50 \% \mathrm{WL}$ and glass properties were predicted and compared to current acceptance criteria. The WL interval over which all EVs were classified as acceptable was determined along with the constraint(s) that limits access to lower or higher WLs. Table 15 summarizes the results of the Variation Stage assessment using this single frit. It should be noted that 
this frit may not be optimal with respect to demonstrating the robustness to compositional variation. ${ }^{*}$ However, its use does provide insight into the impact of the applied variation on the upper WLs over which all EVs are considered acceptable. This in turn sheds light on the ability of the current process control models to provide access to higher WLs for future sludge batches. If access to WLs needed to achieve contractual obligations can not be reached, the results will also identify the models that induce these restrictions or provide guidance for alternative approaches that may be required to meet processing expectations.

Table 15. Results of Variation Stage Assessment for Each Sludge Batch using the $10 \% \mathrm{~B}_{2} \mathrm{O}_{3}, \mathbf{3 \%}$ $\mathrm{Li}_{2} \mathrm{O}, 12 \% \mathrm{Na}_{2} \mathrm{O}$, and $75 \% \mathrm{SiO}_{2}$ Frit.

\begin{tabular}{||c|c|c|c|c|c||}
\hline \hline $\begin{array}{c}\text { Sludge } \\
\text { Batch }\end{array}$ & $\begin{array}{c}\text { Total \# of } \\
\text { Sludge EVs }\end{array}$ & $\begin{array}{c}\text { Lower WL } \\
\text { Constraint }\end{array}$ & $\begin{array}{c}\text { Projected } \\
\text { Operating Window }\end{array}$ & $\begin{array}{c}\text { Upper WL } \\
\text { Constraint }\end{array}$ & $\begin{array}{c}\text { \# of EVs } \\
\text { Failing }\end{array}$ \\
\hline 9 & 8287 & $\mathrm{Al}_{2} \mathrm{O}_{3}$, high $\eta$ & $29-39$ & $\mathrm{~T}_{\mathrm{L}}$ & 5 at $40 \%$ \\
\hline 10 & 8001 & $\mathrm{Al}_{2} \mathrm{O}_{3}$, high $\eta$ & $29-38$ & $\mathrm{~T}_{\mathrm{L}}$ & 11 at $39 \%$ \\
\hline 11 & 7923 & high $\eta$ & $29-38$ & $\mathrm{~T}_{\mathrm{L}}$ & 2 at $39 \%$ \\
\hline 12 & 8605 & high $\eta$ & $34-39$ & $\mathrm{~T}_{\mathrm{L}}$ & 3 at $40 \%$ \\
\hline 13 & 8693 & high $\eta$ & $35-41$ & $\mathrm{~T}_{\mathrm{L}}$ & 28 at $42 \%$ \\
\hline 14 & 8835 & high $\eta$ & $35-41$ & $\mathrm{~T}_{\mathrm{L}}$ & 10 at $42 \%$ \\
\hline 15 & 8831 & high $\eta$ & $32-41$ & $\mathrm{~T}_{\mathrm{L}}$ & 8 at $42 \%$ \\
\hline 16 & 8462 & high $\eta$ & $30-40$ & $\mathrm{~T}_{\mathrm{L}}$ & 80 at $41 \%$ \\
\hline 17 & 8317 & high $\eta$ & $29-38$ & $\mathrm{~T}_{\mathrm{L}}$ & 10 at $39 \%$ \\
\hline
\end{tabular}

The information shown in Table 15 includes: the sludge batch, the total number of sludge EVs for each sludge batch, the constraint(s) limiting access to lower WLs, the projected operating window (or the WL interval over which all EVs are classified as acceptable), the constraint that limits access to higher WLs, and the number of EVs (out of the total) that fail at the upper WL where unacceptable glasses are initially predicted. To aid in the interpretation of the Table 15 information, consider the Variation Stage results for SB9 (first row of data). There are $8287 \mathrm{EV}$ sludge compositions represented by the combinations of the minimum and maximum values for each sludge oxide. The WL interval over which all $8287 \mathrm{EVs}$ are predicted to have acceptable properties is 29 to $39 \%$ WL. Predictions of high viscosity (high $\eta$ ) or low $\mathrm{Al}_{2} \mathrm{O}_{3}$ concentrations (lower than $3 \mathrm{wt} \%$ in glass) restrict access to lower WLs (perhaps not a concern for this study given higher WLs are desired). $\mathrm{T}_{\mathrm{L}}$ predictions limit access to higher WLs. More specifically, 5 of the $8287 \mathrm{EVs}$ result in unacceptable $\mathrm{T}_{\mathrm{L}}$ predictions at $40 \% \mathrm{WL}$ (i.e., the predicted $\mathrm{T}_{\mathrm{L}}$ values fail their respective MAR values), and thus, the operating window over which all EVs are acceptable is restricted to a maximum of $39 \% \mathrm{WL}$.

Given a WL of $40 \%$ is desired to meet future contractual DWPF obligations, does the $10 \% \mathrm{~B}_{2} \mathrm{O}_{3}, 3 \%$ $\mathrm{Li}_{2} \mathrm{O}, 12 \% \mathrm{Na}_{2} \mathrm{O}$, and $75 \% \mathrm{SiO}_{2}$ frit provide any opportunities to meet the WL target? Based on the Nominal Stage assessments in the previous section, this frit provided access to upper WLs of at least as high as $44 \% \mathrm{WL}$ for all eighteen sludge batches. When variation is applied, the ability to target $40 \% \mathrm{WL}$ and maintain all of the EVs as acceptable is sludge batch dependent. Based on the Variation Stage assessment, use of the $10 \% \mathrm{~B}_{2} \mathrm{O}_{3}, 3 \% \mathrm{Li}_{2} \mathrm{O}, 12 \% \mathrm{Na}_{2} \mathrm{O}$, and $75 \% \mathrm{SiO}_{2}$ frit would allow DWPF to target $40 \%$ WL with all of the EVs being classified as "acceptable" for sludge batches 13, 14, 15, and 16. For SB13 and SB14, the operating window over which all of the EVs are considered acceptable is relatively

\footnotetext{
* The "10,3,12,75" frit was listed as an "optimal" frit for SB16 as shown in Table 9.
} 
small: 35-41\% WL. The operating window does increase for SB15 and SB16 but only on the low WL side.

The results of the MAR assessments suggest that the use of the $10 \% \mathrm{~B}_{2} \mathrm{O}_{3}, 3 \% \mathrm{Li}_{2} \mathrm{O}, 12 \% \mathrm{Na}_{2} \mathrm{O}$, and $75 \%$ $\mathrm{SiO}_{2}$ frit is not robust enough for specific sludge batches (SB9, 10, 11, 12 and 17) to allow DWPF to target $40 \% \mathrm{WL}$ while classifying all EVs as acceptable. This may not be surprising given this specific frit was selected based on its ability to tolerate compositional variation over all of the nominal sludge batches and was not necessarily an optimal frit for a specific sludge batch. As a comparison, frits that were identified as being optimal for each specific sludge batch (see Table 2 through Table 10) were assessed against the EVs for their respective sludge batches over the WL interval of $25-50 \%$.

Prior to this assessment, it is noted that the $10 \% \mathrm{~B}_{2} \mathrm{O}_{3}, 3 \% \mathrm{Li}_{2} \mathrm{O}, 12 \% \mathrm{Na}_{2} \mathrm{O}$, and $75 \% \mathrm{SiO}_{2}$ frit was identified as an optimal frit for SB16 (see Table 9) although it did not provide access to the highest WL for the nominal SB16 sludge-only and SWPF-based projections. More specifically, in that Nominal Stage assessment, the projected operating window for the nominal SB16 sludge was $26-48 \%$ WL for both sludge-only and SWPF-based compositions. The application of the sludge EVs has a significant impact by reducing the acceptable processing window. From Table 15, the operating window over which all of the SB16 EVs can be processed with the $10 \% \mathrm{~B}_{2} \mathrm{O}_{3}, 3 \% \mathrm{Li}_{2} \mathrm{O}, 12 \% \mathrm{Na}_{2} \mathrm{O}$, and $75 \% \mathrm{SiO}_{2}$ frit is $30-40 \%$ WL with predictions of $\mathrm{T}_{\mathrm{L}}$ limiting access to higher WLs. This is an eight WL point reduction in the upper WL that is considered achievable based just on the application of sludge variation.

Table 16 summarizes the Variation Stage assessment for SB9 using optimal frits $(8,3,11,78$ and $9,2,12,77$ ) based on the Nominal Stage results (see Table 2). As noted in Table 2, both systems are low viscosity limited at 49\% WL for the nominal sludge-only and SWPF-based flowsheets. A review of the detailed output from the Nominal Stage results also indicates that predictions of $\mathrm{T}_{\mathrm{L}}$ become limiting at $50 \% \mathrm{WL}$ for the sludge-only options but are not limiting at 50\% WL for the SWPF-based cases.

Table 16. Nominal and Variation Stage Assessments for SB9 with “Optimal” Frits.

\begin{tabular}{||l|c|c||}
\hline Nominal Stage & $\mathbf{8 , 3 , 1 1 , 7 8}$ & $\mathbf{9 , 2 , 1 2 , 7 7}$ \\
\hline SO & High $\eta$ & High $\eta$ \\
& $30-48$ & $30-48$ \\
& Low $\eta$ & Low $\eta$ \\
& $\left(\mathrm{T}_{\mathrm{L}}\right.$ at $\left.50 \% \mathrm{WL}\right)$ & $\left(\mathrm{T}_{\mathrm{L}}\right.$ at $\left.50 \% \mathrm{WL}\right)$ \\
\hline SWPF & High $\eta$ & High $\eta$ \\
& $30-48$ & $30-48$ \\
& Low $\eta$ & Low $\eta$ \\
& $\left(\mathrm{T}_{\mathrm{L}}>50 \% \mathrm{WL}\right)$ & $\left(\mathrm{T}_{\mathrm{L}}>50 \% \mathrm{WL}\right)$ \\
\hline Variation Stage & & \\
\hline & High $\eta$ & High $\eta$ \\
& $33-39$ & $34-38$ \\
& $\mathrm{~T}_{\mathrm{L}}$ & $\mathrm{T}_{\mathrm{L}}$ \\
& $($ low $\eta$ at $45 \% \mathrm{WL})$ & (low $\eta$ at $45 \% \mathrm{WL})$ \\
\hline
\end{tabular}

The results of the Variation Stage are enlightening as the WL interval over which all of the EVs (8287) are considered acceptable is highly restricted for both optimal frits $(33-39 \% \mathrm{WL}$ and $34-38 \% \mathrm{WL}$, respectively). Losing access to the lower WLs is not considered to be a show-stopper with respect to programmatic objectives of targeting higher WLs. However, the reduction of the upper WLs over which 
all of the EVs are considered acceptable for SB9 is highly disturbing. The system transitions from being low viscosity limited based on the Nominal Stage assessment at 49\% WL to $\mathrm{T}_{\mathrm{L}}$ limited at $40 \% \mathrm{WL}$ - a 9 to $10 \mathrm{WL}$ percentage point smaller window once variation is applied. When the magnitude of the $\mathrm{T}_{\mathrm{L}}$ and low viscosity shifts are reviewed, one finds that there was only a $3 \mathrm{WL}$ percentage point reduction from where glass systems are acceptable versus not acceptable based on low viscosity predictions once variation is applied. This magnitude (3 to $4 \mathrm{WL}$ point reduction) is consistent with previous results of Variation Stage assessment but pales in comparison to the shift based on $T_{L}$. The $T_{L}$ restrictions for both frits transitioned from $50 \%$ (or greater) with the nominal compositions to 39 or $40 \% \mathrm{WL}$ - an 11 or 12 WL point reduction. These results suggest that the $\mathrm{T}_{\mathrm{L}}$ model is much more sensitive to compositional changes as a result of WLs changes.

\subsection{Discussion: Possible Solutions or Alternative Approaches}

Previous Variation Stage assessments have typically shown a 3 to 5 WL point reduction in the projected operating windows relative to those seen in the Nominal Stage assessments due to the variations applied as compared to the $8-10 \mathrm{WL}$ point reduction being observed in this study. ${ }^{7,8}$ The primary differences have been a transition in: (1) applying variation to only a sludge-only projection instead of both sludgeonly and coupled projections and (2) what has been (or is being) defined as an acceptable WL interval for the Nominal Stage assessment. In previous studies, an "acceptable" operating window for the Nominal Stage assessment was based on a minimum $25 \%$ WL up to a WL in the low 40 s. The lower "acceptable" upper WLs were primarily driven by the lower WLs being targeted in DWPF at that time and access to WLs less than $30 \%$ were deemed critical given the potential for variation in the glass systems likely to be encountered (if only by compositional uncertainties in the SRAT or SME analyses). That is, for previous sludge batches targeting $32-34 \% \mathrm{WL}$, having a glass system projected to satisfy the MAR criteria from $25 \% \mathrm{WL}$ up to WLs in the high 30 s to low 40 s was considered acceptable.

Given the future expectation of $40 \%$ WL (nominally or average), lower WLs (i.e., $<30 \%$ ) are of little interest and thus the acceptable WL interval has shifted. Based on the results shown in this study, the shift in the acceptable WL interval has transitioned the glass forming region into a compositional space that is more sensitive to $T_{L}$ model predictions. More specifically, at these higher WLs, the $T_{L}$ model is becoming more restrictive, resulting in significant reductions in the upper achievable WLs once standard variation is applied. The question becomes what options are available to counter such drastic reductions in the projected operating windows once variation is applied to future sludge batch systems?

One option would be to consider changing the magnitude of the applied variation (i.e., $\pm 7.5 \%$ on majors and $\pm 0.5 \mathrm{wt} \%$ on minors). Although a reduction in these applied values should generally result in higher achievable WLs (for $\mathrm{T}_{\mathrm{L}}$-limited systems) within the Variation Stage assessment, there would no longer be a link between the applied variation and the DWPF process. That is, the application of $\pm 7.5 \%$ on majors and $\pm 0.5 \mathrm{wt} \%$ on minors was first introduced as part of frit development efforts to reflect potential sources of variation in the DWPF process (e.g., SRAT-to-SRAT variation).

One of the questions of interest as part of this evaluation is: Are the variations in sludge compositions introduced during the Variation Stage Assessments unrealistically large given they were established several years ago? To address this question, SRAT Receipt data for Fe and Na from recent SRAT batches (403 through 563) were investigated. These data are provided in Table A1 of the Appendix. Each row of this table provides the average $\mathrm{Fe}$ and average $\mathrm{Na}$ values from the Cold Chem analysis of the SRAT Receipt samples for the indicated batch. The SRAT batches cover processing from Sludge Batch 4 (SB4), Sludge Batch 5 (SB5), and Sludge Batch 6 (SB6) and the rows are grouped by changes to these sludge 
batches due to decants and other additions. It should also be noted that the compositional information covers both sludge-only and coupled operations within each sludge batch.

Table 17 provides summary information for these groups of measurements. Specifically, the number of batches in each group is shown, the average Fe and average Na concentrations for the group, the standard deviation (Std Dev) of the $\mathrm{Fe}$ and of the $\mathrm{Na}$ concentrations for the group, and the percent relative standard deviation (\%RSD) for the $\mathrm{Fe}$ and for the Na concentrations. The \%RSDs provide a point of comparison for the $\pm 7.5 \%$ variation employed during the Variation Stage assessment. In most cases, the $7.5 \%$ is only slightly larger than the 1-sigma variation experienced during the processing of these various groups of SRAT batches. Thus, this review suggests that the variations introduced during the Variation Stage assessment are not unrealistically large. Based on this limited evaluation, it appears that continued application of the $\pm 7.5 \%$ variation is warranted to assess the potential impacts of SRAT-to-SRAT variation on potential SME acceptability decisions.

Table 17. Summary Statistics for the Fe and Na Measurements from Recent SRAT Receipt Batches

\begin{tabular}{||c|c|c|c|c|c|c|c||}
\hline SB Grouping & $\begin{array}{c}\text { \# of } \\
\text { Batches }\end{array}$ & $\begin{array}{c}\text { Mean } \\
\text { Fe wt \% }\end{array}$ & $\begin{array}{c}\text { Mean } \\
\text { Na wt \% }\end{array}$ & $\begin{array}{c}\text { Std Dev } \\
\text { Fe wt \% }\end{array}$ & $\begin{array}{c}\text { Std Dev } \\
\text { Na wt \% }\end{array}$ & $\begin{array}{c}\text { \%RSD } \\
\text { Fe wt \% }\end{array}$ & $\begin{array}{c}\text { \%RSD } \\
\text { Na wt \% }\end{array}$ \\
\hline SB4 - post first decant & 11 & 14.702 & 9.308 & 1.063 & 0.584 & 7.23 & 6.27 \\
\hline SB4 - post Na addition & 17 & 13.435 & 9.681 & 0.750 & 0.585 & 5.58 & 6.04 \\
\hline SB4 - post second decant & 2 & 15.542 & 8.433 & 0.450 & 0.048 & 2.90 & 0.57 \\
\hline SB4 - prior to first decant & 26 & 13.685 & 10.205 & 0.703 & 0.750 & 5.14 & 7.35 \\
\hline SB5 - post decant/Na & 44 & 12.567 & 12.443 & 0.693 & 0.441 & 5.52 & 3.55 \\
\hline SB5 - prior to first decant & 19 & 13.395 & 11.141 & 0.642 & 0.609 & 4.79 & 5.47 \\
\hline SB6 & 33 & 10.636 & 13.146 & 1.078 & 1.154 & 10.14 & 8.78 \\
\hline
\end{tabular}

So what are other options available to avoid the dramatic, negative impacts of the $T_{L}$ model on the projected operating windows? Some options include (but are certainly not limited to): (a) revising the current $T_{L}$ model, ${ }^{*}(b)$ evaluating alternative $T_{L}$ models (e.g., Hanford or Energy Solutions / Vitreous State Laboratory (ES/VSL) models), (c) revising the tank retrieval and blending strategies, or (d) assuming more technical risk for DWPF operations.

A few words on each of these options are provided below. First, consider possible revisions to the current $\mathrm{T}_{\mathrm{L}}$ model. As discussed in Section 6.4, with the exception of $\mathrm{MgO}$, the sludge oxide intervals over which the current $T_{L}$ model was developed encompass the compositional regions of interest up to WLs in the low $40 \mathrm{~s}$ - which include the nominal contractual WL of $40 \%$ for future operations. ${ }^{\dagger}$ Therefore, revisions to the $T_{L}$ model would not necessarily be driven by the results of this MAR assessment study until experimental data suggest significant differences between measured and predicted $T_{L}$ values in this compositional region. However, it is recognized that there could be combinations of oxides that, even if within the model development ranges, could result in significant differences between the measured and predicted $\mathrm{T}_{\mathrm{L}}$. In addition, the Revision 16 projections received from SRR were either sludge-only or SWPF-based projections which may not have included other auxiliary streams such as SCIX. The addition of the SCIX stream is anticipated to lead to significant differences in the concentrations of ${ }^{9}$ expected to introduce $\mathrm{TiO}_{2}$ and $\mathrm{Nb}_{2} \mathrm{O}_{5}$ into the DWPF flowsheet at significant concentrations. In support

\footnotetext{
${ }^{*}$ The $\mathrm{T}_{\mathrm{L}}$ model is identified as a primary model of interest given the results of the MAR assessment. Other models could be evaluated and revised as needed based on existing data or new data developed to "challenge" current model predictions.

$\dagger$ This latter statement excludes the issue of the low $\mathrm{Li}_{2} \mathrm{O}$ content of the "optimal" frits that would ultimately lead to applicability issues of the current $\mathrm{T}_{\mathrm{L}}$ model based on the $\mathrm{Li}_{2} \mathrm{O}$ development ranges identified by Brown et al. (2001).
} 
of the SCIX program, Fox et al. ${ }^{6}$ have investigated $\mathrm{TiO}_{2}$ contents from approximately 3 to $12 \mathrm{wt} \%$ in glass which exceed the $T_{L}$ model development interval ( 0 to $\left.2 \mathrm{wt} \%\right)$. In addition to the increased concentrations of $\mathrm{TiO}_{2}$, the impact of $\mathrm{Nb}_{2} \mathrm{O}_{5}$ on various glass properties is also of interest. In fact, the current $\mathrm{T}_{\mathrm{L}}$ model does not include a $\mathrm{Nb}_{2} \mathrm{O}_{5}$ term. Preliminary data from the SCIX program suggest that the $T_{L}$ model currently under predicts the $T_{L}$ of SCIX-based glasses. ${ }^{4,9}$ Given that, efforts are underway to evaluate the potential to revise the current $T_{L}$ model to more accurately predict $T_{L}$ in this broader compositional region than that over which the $T_{L}$ model was initially developed. The incentive for revising the $T_{L}$ model stems from the initial SCIX data to ensure accurate predictions of $T_{L}$ once these streams are introduced into DWPF. One of the challenges for the current program is to bridge the compositional gap by using revised projections which account for all auxiliary streams coming into DWPF. Once this compositional gap is defined, future MAR assessments should utilize any updated or revised $\mathrm{T}_{\mathrm{L}}$ model to evaluate the impact on achieving future $\mathrm{WL}$ expectations. Revisions to the current $\mathrm{T}_{\mathrm{L}}$ model could take the simplistic form of refitting the current speciation coefficients based on data in these broader compositional regions (e.g., higher $\mathrm{TiO}_{2}, \mathrm{Fe}_{2} \mathrm{O}_{3}, \mathrm{U}_{3} \mathrm{O}_{8}$ concentrations and/or higher WLs) or the more challenging task of the addition of other terms or specifications (such as $\mathrm{Nb}_{2} \mathrm{O}_{5}$ if needed). Revising the current model coefficients is perhaps one of the more simplistic routes assuming qualified data to cover the required region are available. Use of "simplistic" to describe possible changes is a relative term and should not be viewed as a measure of effort or seen as implying that the activities are of short duration in schedule space. Given additional qualified data are available, revisions to the model coefficients could lead to a more accurate prediction of $T_{L}$ and/or lower uncertainties which could ultimately translate into higher WLs if the revised model were used to assess projected operating windows. It is also noted that if the current model is under-predicting the $T_{L}$ for glasses within this compositional region, a revision to the model could lead to further reductions in the projected operating windows.

Prior to the discussion of alternative modeling approaches or acceptance of more processing risk, the issue of sludge retrieval and blending needs to be addressed. Although Revision 16 of the HLW System Plan apparently did not include all of the potential auxiliary streams that DWPF may ultimately have to process, the projections provided must have been based on a planned or assumed tank retrieval, blending, and washing strategy. That is, each sludge batch projection was presumably developed with assumptions made on which tanks would be retrieved, how much material was to be transferred from each tank, the composition of each tank, the washing strategy (accounting for tank volume or space limitations) and potential heel effects (post transfers or during processing from Tank 40). Recognizing that the planned sequencing of sludge batches as defined in Revision 16 may have been driven by (or at least influenced by) both regulatory and/or retrieval constraints, a question of interest is: "If there is flexibility in the retrieval/blending strategy, could an alternative strategy be developed which would allow for contractual WLs to be attained without significant changes to the current glass formulation approaches or models?" If so, SRR should take advantage of the PCCS based MAR computational algorithms developed by SRNL to address this question. More specifically, the SRNL computational algorithms could be used to assess multiple tank retrieval and blending strategies to identify whether options exist that would allow future contractual WLs to be met based strictly on changes to the retrieval and blending strategy. Assuming sludge mass and compositional estimates are known for each tank as well as constraints on tank retrieval sequencing or mass transfers, multiple combinations of future sludge batch projections could be developed and then compared using the MAR computational algorithms. That is, the revised sludge projections could be used as input into the standard MAR assessments to evaluate down stream impacts on projected operating windows for DWPF processing. This type of an assessment could serve as the basis for future revisions to the HLW Systems Plan.

Another alternative approach to gain access to higher WLs is to evaluate other $\mathrm{T}_{\mathrm{L}}$ models or crystallization strategies that have been (or are being) developed for vitrification of HLW at other Department of Energy (DOE) sites (such as Hanford). There are $\mathrm{T}_{\mathrm{L}}$ models developed by Pacific 
Northwest National Laboratory (PNNL) and ES/VSL that could be evaluated with respect to their potential to allow access to compositional regions of interest (i.e., higher WLs) that are being restricted by the current DWPF $T_{L}$ model. To ensure that the models are appropriately compared, the performance of any model that replaces an existing DWPF model in PCCS and used during the MAR assessments must reflect the impact of the uncertainties associated with both the property prediction (PAR) and compositional measurement (MAR). Using an alternative model without these associated uncertainties applied may lead to a false sense of success with respect to access to higher WLs. For example, removing the MAR uncertainties associated with the current $\mathrm{T}_{\mathrm{L}}$ model would ultimately increase the operating windows for those systems that are $\mathrm{T}_{\mathrm{L}}$ limited at higher WLs. However, the increase in operating window size would be a direct result of not applying known uncertainties which would (if this approach is ultimately used to support operations) increase the risk of melter processing issues assuming improvement in melter technology does not compensate for this potential risk.

With respect to increasing risk, issues associated with $T_{L}$ are not waste form affecting (but merely associated with the ability to process a particular glass through the melter). That is, $\mathrm{T}_{\mathrm{L}}$ is strictly a processing issue assuming the primary phase field is a spinel-type crystal and not a crystal type that could ultimately impact durability such as nepheline. Assuming higher processing risk by not applying known uncertainties is probably not under consideration (i.e., ignoring the PAR or MAR criteria). However, higher processing risk could take the form of reducing the current $\mathrm{T}_{\mathrm{L}}$ off-set from $100^{\circ} \mathrm{C}$ to some lower value or selecting a system in which only a limited number of EVs fail $T_{L}$ at WLs of interest based on the Variation Stage assessment. Peeler and Edwards ${ }^{10}$ have shown the impact of reducing the $\mathrm{T}_{\mathrm{L}}$ off-set from $100^{\circ} \mathrm{C}$ to $50^{\circ} \mathrm{C}$ (while still applying the same PAR and MAR uncertainties) on increasing the accessibility to higher WLs for $T_{L}$-limited systems. In that assessment, reducing the $T_{L}$ off-set resulted in an increase in the operating windows for some systems by up to $8 \mathrm{WL}$ points. Although a potentially effective strategy to increase projected operating windows, it is recognized that other operational considerations such as the behavior of the glass in cooler spots of the melter such as the pour spout may limit the applicability of this approach. The decision to implement such a strategy could be viewed as a risk versus reward situation. However, if the current DWPF $T_{L}$ model is found to under-predict $T_{L}$ in these broader compositional regions, then revisions to the $T_{L}$ model to more accurately reflect the true $T_{L}$ may negate the implementation of a smaller $T_{L}$ off-set from which PAR and MAR uncertainties are applied. Another option that could be considered is the replacement of the "standard" $T_{L}$ model approach (i.e., a $T_{L}$ model implemented to avoid massive devitrification within the glass pool) by a volume percent crystallization approach (one in which a certain percentage of crystals at some pre-defined temperature) is allowed within the melter. This latter approach is currently being explored by Hanford to meet WL expectations. That is, by allowing a certain volume fraction of crystals within the melt pool, it is anticipated that higher WLs can be targeted to allow contractual WL obligations to be met. Operational risks or potential technological mitigating factors that may come into play are the percentage of crystals in the melt pool, forced convection via bubblers to mitigate settling, high glass throughput rates to mitigate settling potential, etc. If DWPF elects to pursue such an approach, detailed assessments of the risks to operations must be fully evaluated prior to implementation.

Based on the MAR assessments performed in this study, it is clear that meeting future contractual WL targets in DWPF will be difficult. How should these concerns be addressed? The authors have identified possible options that could be pursued to allow DWPF to meet future WL expectations. These included a change in the retrieval/blending strategy used in developing future sludge batches, potential changes to the implementation approach of the process control models, updating the current models implemented into PCCS, replacing existing models with alternative models, or assuming more processing risk through alternative metrics to define "acceptable" operating windows. The ultimate question that must be addressed prior to implementation within DWPF is: What information will be required by the facility to lower the risk of the change to an acceptable level? That is, how much research and development and/or melter testing will be required to lower the risk of the proposed change to a manageable level prior to 
SRNL-STI-2011-00358

Revision 0

implementation? And how long will it take to reach that acceptable level of risk? When could the changes be implemented into DWPF and how does that time line align with WL obligations for future operations?

\subsection{Summary}

Based on the results of the Nominal Stage assessments of the SB9 through SB17 projections, projected operating windows of at least as low as 30\% with upper WLs exceeding $46 \%$ WL are achievable with current PCCS models for all future sludge batches (sludge-only and SWPF based). Although these operating windows are encouraging from the perspective of meeting the future contractual WL obligations of $40 \%$, a significant concern is the realization that the Nominal Stage assessments do not account for potential sludge/waste variation. The results of the Variation Stage assessments show significant, negative reductions in the projected operating windows over which all of the extreme vertices can be processed. Application of the variation typically resulted in an 8 to $10 \mathrm{WL}$ point reduction in the operating window as compared to the Nominal Stage assessment window. This significant reduction occurred for "optimal" frits as well as "robust" frits suggesting that the ability to target a nominal WL of $40 \%$ while maintaining all of the extreme vertices as acceptable will be extremely challenging for future DWPF operations based on the Revision 16 projections.

Based on the MAR assessments performed in this study, it is clear that meeting future contractual WL targets in DWPF will be difficult. That is, if one continues to use the existing PCCS models, the current (or defined) WL metrics for acceptability (operating windows), and the standard system approaches or assumptions (e.g., magnitude of variation applied to the sludge/waste compositions) the ability to meet future contractual WL obligations will be extremely challenging. These results obviously indicate or dictate the need for alternative approaches to be considered. Potential changes to the development strategy include: (a) integrating MAR assessments into the retrieval/blending strategy used in developing future sludge batches, (b) updating or replacing current models implemented into PCCS, or (c) assuming more processing risk through alternative metrics to define "acceptable" operating windows. The decision to implement alternative strategies, models, or approaches may ultimately be based on a balance between risk (operational) and reward (WL expectations). 
SRNL-STI-2011-00358

Revision 0

\subsection{Recommendations}

Based on the results of this study, the likelihood of SRR meeting future contractual WLs (40\%) for all sludge batches using the current approach is highly unlikely. To support future operations, all possible options or alternative approaches must be considered. The recommendations provided below are classified into two categories: (1) sludge projections and (2) updates or changes to PCCS. Although classifying the recommendations provides structure with respect to presentation or follow-on discussions, it must be recognized that there is a high level of interdependence among most (if not all) of the potential options that could be pursued. With this in mind, development and prioritization of the specific paths forward need to be made in a timely manner. The development and prioritization process should also consider (if not be based) on the following facts: the different options could be worked in parallel or in series; they vary in the degree of complexity which could set up the need for iterative assessments; they will have different implementation schedules; and they may have varying degrees of operational risk. To this end, the high-level recommendations provided below are the starting point for discussions to strategically define a path forward that will provide the highest probability of success. To support future WL obligations, development of alternative pathways must not only be based on strategic technical solutions or approaches but also need to be implementable in a timely manner so as not to delay the attainment of contractual goals. It should also be recognized that near-term strategies to attain higher WLs may differ from longer term strategies, if required.

In the area of sludge/waste projections:

D Integrate the SRNL MAR based algorithms into the development of future sludge batch projections or HLW systems planning efforts to determine if there are alternative tank retrieval or blending strategies that could be pursued to provide access to higher WLs.

o The algorithms could rely upon current PCCS models, revisions to these models, or new models and/or approaches (see discussion below for more detail).

U Update the Revision $16 \mathrm{HLW}$ System Plan projections to account for the introduction or termination of all secondary or auxiliary streams.

In the area of updates or changes to PCCS:

Integrate with the SCIX program to monitor or support development of $\mathrm{T}_{\mathrm{L}}$ data within a compositional region of interest to DWPF that will be used to update or revise the current $T_{L}$ model and ultimately be used to re-evaluate projected operating windows for future sludge batches.

o Identify existing and qualified data that could be used to determine the need for a revision or to validate the current PCCS $\mathrm{T}_{\mathrm{L}}$ model. It should be noted that updates or revisions to other current PCCS models (in particular the viscosity model) could also be evaluated given existing and qualified data in the compositional region of interest.

o Assess whether additional experimental data are needed to fill compositional gaps that may exist between existing data and the DWPF compositional region of interest.

- As an example, higher $\mathrm{MnO}, \mathrm{Fe}_{2} \mathrm{O}_{3}$, and $\mathrm{U}_{3} \mathrm{O}_{8}$ and lower $\mathrm{MgO}$ and $\mathrm{Li}_{2} \mathrm{O}$ containing glasses may need to be further explored if higher WLs are to be targeted.

Identify alternative models and/or approaches that could be used to assess their viability to meet future contractual WL obligations.

o Evaluate the compositional regions over which alternative models or approaches were developed to ensure applicability. 
SRNL-STI-2011-00358

Revision 0

Perform an assessment of how the implementation of the $\mathrm{T}_{\mathrm{L}}$ model (or alternative model) is related to behavior observed in the pour spout.

\subsection{References}

1. C.C. Herman, D.K. Peeler, T.B. Edwards, M.E. Stone, and M.E. Smith, "Process Changes to DWPF to Increase Throughput and Incorporate Salt Streams," Savannah River National Laboratory, Aiken, SC, Report No. WSRC-STI-2007-00320, Revision 0, 2007.

2. D.P. Chew and B.A. Hamm, "Liquid Waste System Plan, Revision 16," Savannah River Remediation, Aiken, SC, Report 2009.

3. D.K. Peeler and T.B. Edwards, "Projected Operating Windows for Various Sludge Batch 2/3 Blends: A Progression from a Par to a Mar Assessment," Westinghouse Savannah River Company, Aiken, SC, Report 2001.

4. K.M. Fox, T.B. Edwards, and M.E. Stone, "Paper Study Evaluation of the Introduction of Small Column Ion Exchange (SCIX) Waste Streams to the Defense Waste Processing Facility," Savannah River National Laboratory, Aiken, SC, Report 2010.

5. K.G. Brown, R.L. Postles, and T.B. Edwards, "SME Acceptability Determination for DWPF Process Control," Savannah River National Laboratory, Aiken, SC, Report No. WSRC-TR-9500364, Rev. 5, 2006.

6. K.G. Brown, C.M. Jantzen, and G. Ritzhaupt, "Relating Liquidus Temperature to Composition for Defense Waste Processing Facility (DWPF) Process Control," Westinghouse Savannah River Company, Aiken, SC, Report No. WSRC-TR-2001-00520, Revision 0, 2001.

7. D.K. Peeler and T.B. Edwards, "Model Based Assessments for Sb4 Washing Options: 1.2m Batch $/ 0.91 \mathrm{~m}$ Blend and $1.4 \mathrm{~m}$ Batch/0.96m Blend," Washington Savannah River Company, Aiken, SC, Report No. WSRC-STI-2006-00006, Revision 0, 2006.

8. D.K. Peeler, T.B. Edwards, and K.M. Fox, "Sludge Batch 4 (Sb4): Model Based Assessment of the February 2007 Sludge Projection," Westinghouse Savannah River Company, Aiken, SC, Report 2007.

9. K.M. Fox, T.B. Edwards, and F.C. Johnson, "Summary Report on Potential Impacts of Small Column Ion Exchange on DWPF Glass Formulation," Savannah river National Laboratory, Aiken, SC, Report 2011.

10. D.K. Peeler and T.B. Edwards, "Impact of Reducing the $100^{\circ} \mathrm{C}$ Liquidus Temperature Offset on Waste Loading Targets," Savannah River National Laboratory, Aiken, SC, Report 2010. 
SRNL-STI-2011-00358

Revision 0

Appendix A. SRAT Data 
SRNL-STI-2011-00358

Revision 0

Table A1. Average Fe and Na Measurements for SRAT Receipt Samples for Batches 403 through 563

\begin{tabular}{|c|c|c|c|c|c|c|c|c|c|}
\hline SB Grouping & Decants/Additions & Batch \# & Fe wt \% & Na wt \% & SB Grouping & Decants/Additions & Batch \# & Fe wt \% & Na wt \% \\
\hline SB4 - prior to first decant & Prior & 403 & 13.397 & 10.787 & SB5 - post decant $/ \mathrm{Na}$ & Post Decants and $\mathrm{Na}$ & 489 & 13.519 & 12.086 \\
\hline SB4 - prior to first decant & Prior & 404 & 13.734 & 10.258 & SB5 - post decant $/ \mathrm{Na}$ & Post Decants and Na & 490 & 12.300 & 13.603 \\
\hline SB4 - prior to first decant & Prior & 405 & 13.597 & 10.407 & SB5 - post decant/Na & Post Decants and $\mathrm{Na}$ & 491 & 12.523 & 11.899 \\
\hline SB4 - prior to first decant & Prior & 406 & 14.013 & 10.461 & SB5 - post decant/Na & Post Decants and Na & 492 & 12.744 & 11.758 \\
\hline SB4 - prior to first decant & Prior & 407 & 13.100 & 10.031 & SB5 - post decant/Na & Post Decants and $\mathrm{Na}$ & 493 & 13.249 & 12.352 \\
\hline SB4 - prior to first decant & Prior & 408 & 14.111 & 10.397 & SB5 - post decant/Na & Post Decants and Na & 494 & 12.915 & 12.184 \\
\hline SB4 - prior to first decant & Prior & 409 & 13.692 & 10.306 & SB5 - post decant $/ \mathrm{Na}$ & Post Decants and Na & 495 & 14.033 & 12.623 \\
\hline SB4 - prior to first decant & Prior & 410 & 14.270 & 10.041 & SB5 - post decant/Na & Post Decants and Na & 496 & 12.823 & 12.262 \\
\hline SB4 - prior to first decant & Prior & 411 & 14.607 & 10.581 & SB5 - post decant $/ \mathrm{Na}$ & Post Decants and $\mathrm{Na}$ & 497 & 12.904 & 12.014 \\
\hline SB4 - prior to first decant & Prior & 412 & 14.244 & 9.935 & SB5 - post decant/Na & Post Decants and $\mathrm{Na}$ & 498 & 13.160 & 12.435 \\
\hline SB4 - prior to first decant & Prior & 413 & 13.004 & 9.798 & SB5 - post decant/Na & Post Decants and Na & 499 & 12.310 & 12.484 \\
\hline SB4 - prior to first decant & Prior & 414 & 15.559 & 11.241 & SB5 - post decant/Na & Post Decants and $\mathrm{Na}$ & 500 & 11.720 & 11.988 \\
\hline SB4 - prior to first decant & Prior & 415 & 13.428 & 9.705 & SB5 - post decant/Na & Post Decants and Na & 501 & 13.086 & 12.629 \\
\hline SB4 - prior to first decant & Prior & 416 & 14.044 & 9.902 & SB5 - post decant/Na & Post Decants and Na & 502 & 12.142 & 13.101 \\
\hline SB4 - prior to first decant & Prior & 417 & 12.983 & 10.107 & SB5 - post decant $/ \mathrm{Na}$ & Post Decants and Na & 503 & 10.722 & 13.101 \\
\hline SB4 - prior to first decant & Prior & 418 & 12.132 & 9.407 & SB5 - post decant/Na & Post Decants and $\mathrm{Na}$ & 504 & 11.014 & 12.831 \\
\hline SB4 - prior to first decant & Prior & 419 & 13.340 & 10.112 & SB5 - post decant $/ \mathrm{Na}$ & Post Decants and Na & 505 & 12.736 & 12.143 \\
\hline SB4 - prior to first decant & Prior & 420 & 13.698 & 10.999 & SB5 - post decant/Na & Post Decants and Na & 506 & 12.903 & 12.329 \\
\hline SB4 - prior to first decant & Prior & 421 & 14.464 & 7.335 & SB5 - post decant $/ \mathrm{Na}$ & Post Decants and Na & 507 & 12.253 & 11.821 \\
\hline SB4 - prior to first decant & Prior & 422 & 12.805 & 10.043 & SB5 - post decant/Na & Post Decants and $\mathrm{Na}$ & 508 & 12.847 & 12.224 \\
\hline SB4 - prior to first decant & Prior & 423 & 14.447 & 9.768 & SB5 - post decant/Na & Post Decants and Na & 509 & 12.601 & 12.423 \\
\hline SB4 - prior to first decant & Prior & 424 & 13.138 & 11.121 & SB5 - post decant/Na & Post Decants and $\mathrm{Na}$ & 510 & 12.095 & 12.422 \\
\hline SB4 - prior to first decant & Prior & 425 & 13.909 & 10.267 & SB5 - post decant/Na & Post Decants and Na & 511 & 11.744 & 12.474 \\
\hline SB4 - prior to first decant & Prior & 426 & 13.768 & 11.084 & SB5 - post decant/Na & Post Decants and Na & 512 & 12.009 & 12.703 \\
\hline SB4 - prior to first decant & Prior & 427 & 13.332 & 10.534 & SB5 - post decant/Na & Post Decants and Na & 513 & 12.400 & 12.667 \\
\hline SB4 - prior to first decant & Prior & 428 & 12.992 & 10.696 & SB5 - post decant/Na & Post Decants and $\mathrm{Na}$ & 514 & 12.205 & 12.766 \\
\hline SB4 - post first decant & Post & 438 & 12.422 & 10.445 & SB5 - post decant $/ \mathrm{Na}$ & Post Decants and Na & 515 & 12.251 & 13.096 \\
\hline SB4 - post first decant & Post & 439 & 14.430 & 9.471 & SB5 - post decant/Na & Post Decants and Na & 516 & 11.875 & 11.926 \\
\hline SB4 - post first decant & Post & 440 & 15.026 & 9.099 & SB5 - post decant $/ \mathrm{Na}$ & Post Decants and Na & 517 & 12.173 & 12.917 \\
\hline SB4 - post first decant & Post & 441 & 15.091 & 9.018 & SB5 - post decant/Na & Post Decants and $\mathrm{Na}$ & 518 & 12.269 & 12.954 \\
\hline SB4 - post first decant & Post & 442 & 13.992 & 8.713 & SB5 - post decant $/ \mathrm{Na}$ & Post Decants and Na & 519 & 12.315 & 12.529 \\
\hline SB4 - post first decant & Post & 443 & 16.472 & 10.365 & SB5 - post decant/Na & Post Decants and $\mathrm{Na}$ & 520 & 12.448 & 12.389 \\
\hline SB4 - post first decant & Post & 444 & 14.676 & 8.847 & SB5 - post decant/Na & Post Decants and $\mathrm{Na}$ & 521 & 12.291 & 12.687 \\
\hline SB4 - post first decant & Post & 445 & 15.502 & 9.004 & SB5 - post decant/Na & Post Decants and Na & 522 & 12.197 & 13.025 \\
\hline SB4 - post first decant & Post & 446 & 15.122 & 9.274 & SB5 - post decant/Na & Post Decants and Na & 523 & 13.568 & 12.901 \\
\hline SB4 - post first decant & Post & 447 & 15.277 & 9.273 & SB5 - post decant/Na & Post Decants and Na & 524 & 13.441 & 12.837 \\
\hline SB4 - post first decant & Post & 448 & 13.710 & 8.884 & SB5 - post decant/Na & Post Decants and Na & 525 & 13.242 & 12.531 \\
\hline SB4 - post second decant & Post Decant 2 & 449 & 15.860 & 8.467 & SB5 - post decant/Na & Post Decants and $\mathrm{Na}$ & 526 & 12.485 & 11.941 \\
\hline SB4 - post second decant & Post Decant 2 & 450 & 15.223 & 8.399 & SB5 - post decant/Na & Post Decants and $\mathrm{Na}$ & 527 & 12.971 & 12.612 \\
\hline SB4 - post Na addition & Post Na Addition & 451 & 15.001 & 8.541 & SB5 - post decant/Na & Post Decants and Na & 528 & 12.043 & 12.514 \\
\hline SB4 - post Na addition & Post Na Addition & 452 & 12.802 & 10.142 & SB5 - post decant/Na & Post Decants and $\mathrm{Na}$ & 529 & 11.833 & 11.854 \\
\hline SB4 - post Na addition & Post $\mathrm{Na}$ Addition & 453 & 13.960 & 9.925 & SB5 - post decant/Na & Post Decants and $\mathrm{Na}$ & 530 & 13.014 & 11.783 \\
\hline SB4 - post Na addition & Post Na Addition & 454 & 13.684 & 10.193 & SB6 & SB6 start & 531 & 12.152 & 12.354 \\
\hline SB4 - post Na addition & Post Na Addition & 455 & 12.086 & 8.398 & SB6 & & 532 & 10.950 & 12.842 \\
\hline SB4 - post Na addition & Post Na Addition & 456 & 13.488 & 9.873 & SB6 & & 533 & 12.238 & 13.325 \\
\hline SB4 - post Na addition & Post Na Addition & 457 & 13.654 & 10.161 & SB6 & & 534 & 10.902 & 12.890 \\
\hline SB4 - post Na addition & Post Na Addition & 458 & 13.567 & 9.609 & SB6 & & 535 & 10.883 & 12.778 \\
\hline SB4 - post Na addition & Post Na Addition & 459 & 13.452 & 9.735 & SB6 & & 536 & 10.609 & 12.256 \\
\hline SB4 - post Na addition & Post $\mathrm{Na}$ Addition & 460 & 13.373 & 9.473 & SB6 & & 537 & 11.428 & 12.935 \\
\hline SB4 - post Na addition & Post Na Addition & 461 & 13.601 & 9.799 & SB6 & & 538 & 11.391 & 14.403 \\
\hline SB4 - post Na addition & Post $\mathrm{Na}$ Addition & 462 & 13.729 & 9.250 & SB6 & & 539 & 10.796 & 13.377 \\
\hline SB4 - post Na addition & Post Na Addition & 463 & 14.018 & 9.262 & SB6 & & 540 & 10.814 & 15.508 \\
\hline SB4 - post Na addition & Post Na Addition & 464 & 14.134 & 9.820 & SB6 & & 541 & 6.402 & 8.510 \\
\hline SB4 - post Na addition & Post $\mathrm{Na}$ Addition & 465 & 12.295 & 9.587 & SB6 & & 542 & 11.228 & 14.438 \\
\hline SB4 - post Na addition & Post Na Addition & 466 & 13.422 & 10.061 & SB6 & & 543 & 11.794 & 13.591 \\
\hline SB4 - post Na addition & Post Na Addition & 467 & 12.140 & 10.743 & SB6 & & 544 & 11.343 & 13.146 \\
\hline SB5 - prior to first decant & SB5 start & 468 & 12.592 & 11.462 & SB6 & & 545 & 10.951 & 12.546 \\
\hline SB5 - prior to first decant & Prior & 469 & 12.777 & 10.802 & SB6 & & 546 & 11.525 & 12.254 \\
\hline SB5 - prior to first decant & Prior & 470 & 12.902 & 9.749 & SB6 & & 547 & 11.203 & 13.482 \\
\hline SB5 - prior to first decant & Prior & 471 & 13.806 & 11.157 & SB6 & & 548 & 10.964 & 12.693 \\
\hline SB5 - prior to first decant & Prior & 472 & 14.645 & 10.915 & SB6 & & 549 & 11.010 & 11.914 \\
\hline SB5 - prior to first decant & Prior & 473 & 13.479 & 10.323 & SB6 & & 550 & 9.099 & 14.489 \\
\hline SB5 - prior to first decant & Prior & 474 & 14.228 & 11.897 & SB6 & & 551 & 10.603 & 13.022 \\
\hline SB5 - prior to first decant & Prior & 475 & 12.473 & 11.196 & SB6 & & 552 & 9.816 & 13.060 \\
\hline SB5 - prior to first decant & Prior & 476 & 13.771 & 11.233 & SB6 & & 553 & 9.780 & 13.539 \\
\hline SB5 - prior to first decant & Prior & 477 & 13.153 & 10.824 & SB6 & & 554 & 8.892 & 12.204 \\
\hline SB5 - prior to first decant & Prior & 478 & 14.219 & 11.537 & SB6 & & 555 & 9.920 & 13.351 \\
\hline SB5 - prior to first decant & Prior & 479 & 13.679 & 11.238 & SB6 & & 556 & 10.960 & 13.008 \\
\hline SB5 - prior to first decant & Prior & 480 & 12.671 & 9.946 & SB6 & & 557 & 11.047 & 13.231 \\
\hline SB5 - prior to first decant & Prior & 481 & 14.181 & 11.494 & SB6 & & 558 & 11.083 & 13.138 \\
\hline SB5 - prior to first decant & Prior & 482 & 13.158 & 11.469 & SB6 & & 559 & 10.213 & 12.989 \\
\hline SB5 - prior to first decant & Prior & 483 & 13.062 & 11.147 & SB6 & & 560 & 9.571 & 14.499 \\
\hline SB5 - prior to first decant & Prior & 484 & 13.414 & 12.063 & SB6 & & 561 & 10.393 & 13.621 \\
\hline SB5 - prior to first decant & Prior & 485 & 12.664 & 11.632 & SB6 & & 562 & 10.693 & 14.160 \\
\hline SB5 - prior to first decant & Prior & 486 & 13.639 & 11.591 & SB6 & & 563 & 10.332 & 14.261 \\
\hline
\end{tabular}




\section{Distribution:}
A. B. Barnes, 999-W
D. A. Crowley, 773-43A
S. D. Fink, 773-A
B. J. Giddings, 786-5A
C. C. Herman, 999-W
S. L. Marra, 773-A
A. M. Murray, 773-A
F. M. Pennebaker, 773-42A
W. R. Wilmarth, 773-A
J. W. Amoroso, 999-W
A. L. Billings, 999-W
D.C. Bumgardner, 766-H
K. M. Fox, 999-W
J. M. Gillam, 766-H
B. A. Hamm, 766-H
P.J. Hill, 766-H
J. F. Iaukea, 704-30S
C.M. Jantzen, 773-A
F. C. Johnson, 999-W
D.B. Little, 766-H
D. W. McIlmoyle, 766-H
J. E. Occhipinti, 704-S
D. K. Peeler, 999-W
B. R. Pickenheim, 999-W
J. W. Ray, 704-S
H. B. Shah, 766-H
K. R. Shah, 704-S
D. C. Sherburne, 704-S
A. V. Staub, 704-27S
M. E. Stone, 999-W
J. R. Zamecnik, 999-W
P. R. Jackson, 703-46A
K. H. Subramanian, 766-H
M. A. Broome, 704-29S
R. N. Hinds, 704-S
J. P. Vaughan, 773-41A
J. M. Bricker, 704-27S
T. L. Fellinger, 704-26S
E. W. Holtzscheiter, 704-15S
M. T. Keefer, 766-H
H. M. Pittman, 704-27S 